\title{
7. MESOZOIC CHALKS BENEATH THE CAROLINE ABYSSAL PLAIN: DSDP SITE 199
}

\author{
The Shipboard Scientific Party ${ }^{1}$
}

\section{SITE DATA}

Occupied: $23-26$ Oct. 1971

Position: East margin of Caroline Abyssal Plain north of the Caroline Islands; lat $13^{\circ} 30.8^{\prime} \mathrm{N}$

long $156^{\circ} 10.3^{\prime} \mathrm{E}$

Water Depth: 6090 meters

Number of Cores: 13

Total Penetration: 565.5 meters

Deepest Unit Recovered: Brown lithified tuff below late Campanian limestone.

Main Results: The mid-miocene to Pliocene turbidites indicate that the Caroline Abyssal Plain existed as early as the mid-Miocene. The relatively thick PaleoceneCampanian nannofossil limestones may represent deposition during the passage of this deep-water site across the Equator. The lithified tuff may record the last eruption of the volcanoes which now exist as guyots along the eastern margin of the Caroline Abyssal Plain. Basement was not reached but apparently lies at least 200 meters deeper than the drill penetrated and may be quite ancient.

\section{BACKGROUND}

Site 198 had been terminated by a failure of the main swivel, requiring a run to Guam to pick up parts and make repairs. On departing Guam, the ship proceeded to the east, crossing the Mariana Trench and the Mariana Basin. It had been hoped that the basin could be drilled east of the Trench, but only one area presented sufficient cover for spudding in. This fact was recognized too late. The main portion of the basin is highly reflective, and almost no penetration can be seen on the seismic reflection records. No upper transparent layer is present over this wide, smooth area. It is quite possible that the reflector surface is composed of turbidites derived from the Caroline Islands to the south, and it is further possible that these deposits could be easily penetrated, but the possibility exists that the turbidites may now be chert. If we had not been so short on time and bottom hole assemblies, it would have

\footnotetext{
${ }^{1}$ Bruce C. Heezen, Lamont-Doherty Geological Observatory; Ian D. MacGregor, University of California, Davis; Helen P. Foreman, Oberlin College; George Forristall, Eidgenössische Technische Hochschule, Zürich; H. Hekel, Queensland Geological Survey, Brisbane; Reinhard Hesse, Technische Hochschule, Munich; Robert H. Hoskins, New Zealand Geological Survey, Lower Hutt; E. John W. Jones, University College, London; Ansis Kaneps, Scripps Institution of Oceanography, La Jolla; Valeri A. Krasheninnikov, Academy of Sciences, Moscow; Hakuyu Okada, Kagoshima University, Japan; Michael H. Ruef, Washington Department of Ecology, Olympia.
}

been interesting to go to the bottom and test the drilling of the strong reflector.

A track was taken toward the eastern margin of the abyssal plain and here a 40-meter upper transparent layer was found within 15 miles of a seamount which marks the eastern edge of the plain at that spot. It was decided to drill, and the ship returned to a spot where, not only 40 meters of upper transparent layer were present, but deeper reflectors appeared beneath the highly reflective layer. These were initially below the thin upper transparent layer. However, further discussion made it apparent that the drillers would be unwilling to attempt drilling if the reflector showed any resistance; so it was decided to continue the search for a 70-meter thickness of upper transparent layer. This was found along the eastern margin of the abyssal plain. The acoustic sequence showed approximately 70 meters transparent, approximately 100 meters opaque, and approximately 100 meters lower transparent on a definite reflector which it was judged could either be basement or another sedimentary horizon. The objective of drilling the hole was to determine the geologic history of the area and, if possible, to date basement. However, the proximity of several large seamounts unfortunately left the attainment of the last objective uncertain. In any case, it was decided that if 70 meters of transparent sediment was needed to drill and if the opaque reflector of the plain was chert or directly underlain by chert, Site 199 would be the only site in the Mariana Basin. However, if the strong reflector at Site 199 was found to be easily drilled turbidites, then an additional hole could be located in the plain to the west of Site 199 .

The location and bathymetry of Site 199 are shown in Figures 1 and 2, respectively, and seismic profiles across the site are given in Figures 3 and 4.

\section{OPERATIONS}

The site was reached at 0245 on 23 October 1971. The beacon had not been tested; so it was dropped after the ship stopped. Hole 199 was spudded in at 1830 on 23 October and the bit washed in 57 meters before Core 1 was cut (6157.5-6167 meters, see Table 1).

Continuous coring was attempted from the lower part of the upper transparent layer into the opaque layer (Cores 1-4). The opaque layer turned out to be easily penetrated turbidites consisting of silty zeolitic clays which comprise the main body of sediments on the adjacent Caroline Abyssal Plain. Core 4 proved to still be in turbidites; the bit was washed ahead to 143 meters and Core 5 cut, still in relatively soft sediments. The hole was washed ahead to 200 meters and Core 6 cut. This, too, was Miocene turbidites. The hole was washed ahead to 285 meters where a change in drilling rate indicated a lithologic boundary. Core 7 consisted of limestone and chert. The section was 


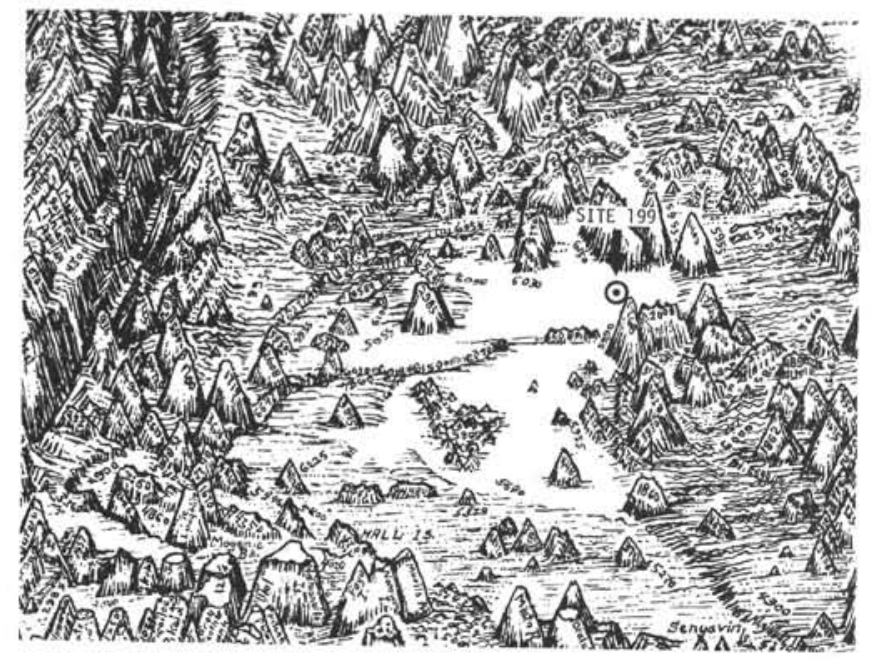

Figure 1. Location of Site 199.

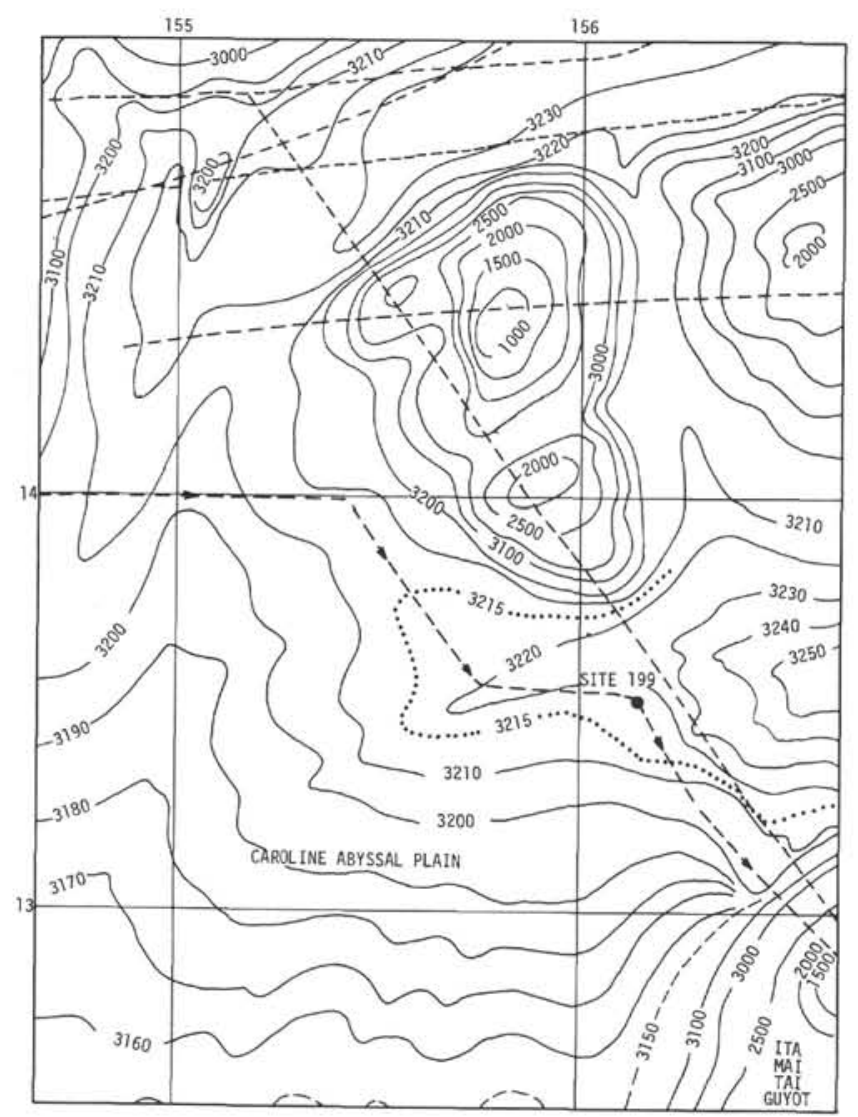

Figure 2. Bathymetry in the vicinity of Site 199 (based on various sounding lines). Contour interval 100 tau (1 tau $=1 / 400 \mathrm{sec}$ ).

continuously cored from Core 7 through Core 9 . The swell began to increase somewhat and it was decided to drill ahead with the center bit until some change in drilling suggested that coring would be appropriate. Core 10 was cut at 371 meters and proved to be limestone similar to that found above. Core 10 was taken immediately below Core 9. Drilling was still relatively easy, but the swell continued to increase; so to save time and in an attempt to sample the deeper section, the core barrel was inserted instead of the center bit and the interval between Core 11 and Core 12 was drilled. Core 12 , at 437.5 meters, was still Late Cretaceous limestone. While the core barrel was being pumped down for Core 13, the Chief Scientists were informed that in the judgement of the drilling personnel, swell conditions were too hazardous to allow additional drilling. Site 199 was abandoned at 1415 on 25 October.

\section{NATURE OF THE SEDIMENTS}

Thirteen cores were obtained from this site with excellent recovery rates except for the last, which consisted of a core catcher sample only.

The cored sedimentary section at Site 199 can be divided into eight main lithologic units, from $\mathrm{A}$ to $\mathrm{H}$ in descending order. A summary of the lithology of each unit is given in Table 2 (see also Figures 5 and 6).

Of these units, the upper six, units $A$ to $F$, are characterized by brown clay, ash, and radiolarian ooze. Nannofossil turbidites with significant amounts of foraminifera and radiolaria are found interbedded in the upper part of this sequence. At least one of the layers (Core 1, Section 4) is well graded. Isolated displaced nannofossils are occasionally present in the clays and ashes due to either slumping, drilling disturbances, or burrowing. Small fragments of cross- or parallel-laminated volcanogenic siltstone are frequently present throughout the sequence.

In sharp contrast to the upper sequence, units $\mathrm{G}$ and $\mathrm{H}$ consist of interbedded autochthonous chalk, limestone, chert, and tuff.

The lithology and sedimentology of these deposits suggest that the upper sequence was deposited below the calcium-carbonate compensation depth, and with significant intercalations of pelagic carbonate redeposited by turbidity currents; whereas, the lower sequence (units G and $\mathrm{H}_{\text {, }}$ was deposited above the carbonate compensation depth. Thus, considerable subsidence of the seafloor or changes in the depth of the carbonate compensation level must have taken place between the periods of deposition of these sequences.

\section{Core 1 (57.5-67 Meters)}

This core consists of early Pliocene (or ?younger) sediments plus reworked ?Eocene-Oligocene material. The sediments of an incompletely recovered Section 1 consist of two distinct types. The upper, somewhat disturbed clay of moderate brown color is underlain by a pale orange, nannofossil turbidite with about 5 percent foraminifera. The fully recovered sediments of Section 2 comprise the lower part of the pale orange nannofossil turbidite in Section 1 except for the bottom $9 \mathrm{~cm}$, which is pale grayish brown clay. The boundary between the nannofossil turbidite and the clay is sharp. The nannofossil turbidite occasionally contains small patches of lighter colored sediment of the same composition.

Section 3, whose sediments are also completely recovered, is basically composed of alternations of pale orange to pale yellowish brown nannofossil turbidite (30 to $60 \mathrm{~cm}$ thick) and dark yellowish brown clay $(50$ to $80 \mathrm{~cm}$ thick). The boundaries between the two layers are always clear but never horizontal. These oblique boundaries seem to be original, but it is difficult to decide whether they are 


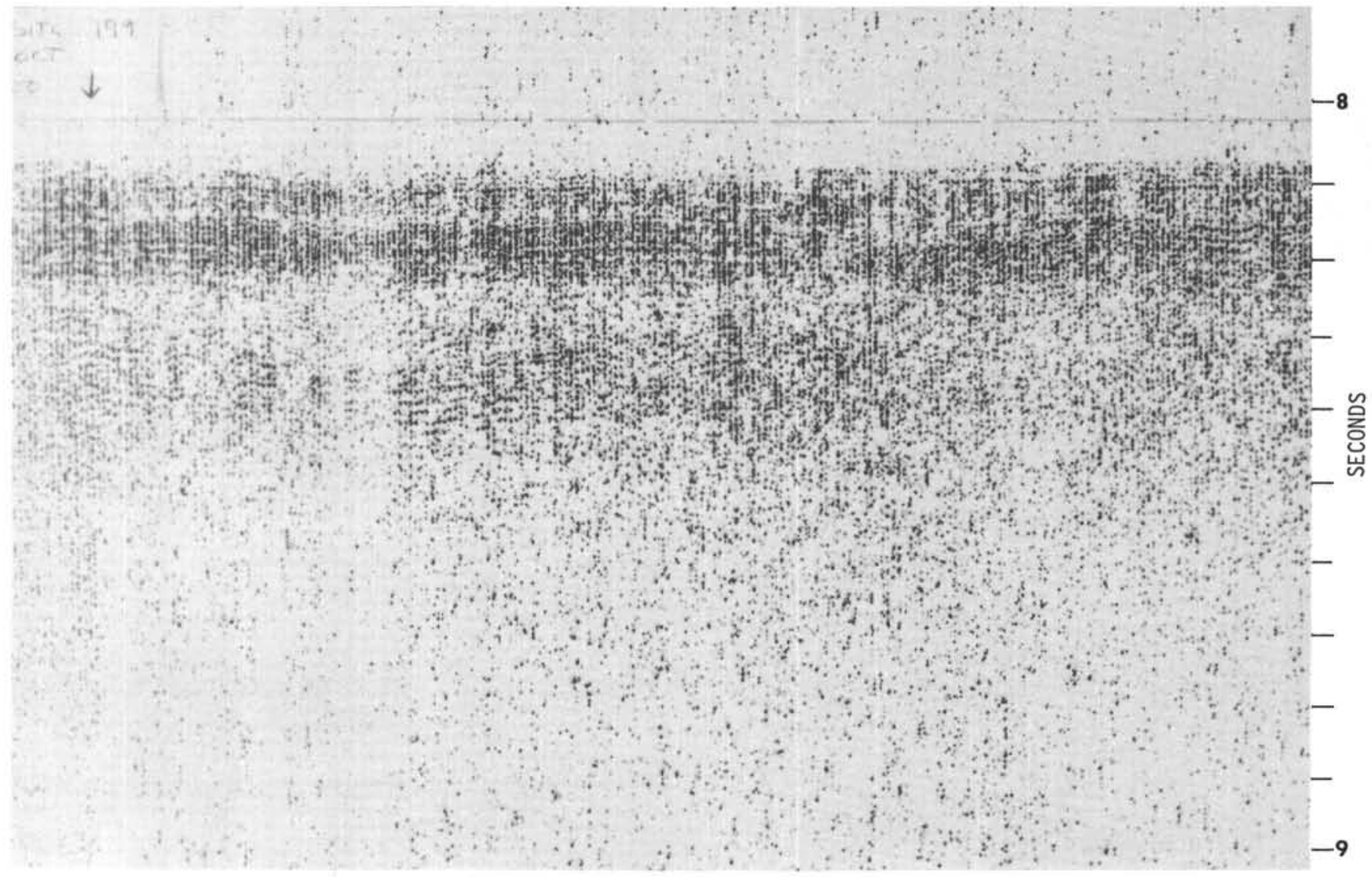

Figure 3. Glomar Challenger seismic profile across Site 199 on site approach.

erosional or due to deformation. Other structures worthy of notice are small patches or lumps of nannofossil ooze often found in the clay layers and patches of clay found in the nannofossil turbidite layers, which were probably produced in the coring process.

The sediments of Section 4 also consist of alternation of a pale yellowish brown to very pale orange nannofossil turbidite and moderate to dark yellowish brown clay. The most interesting structure is detected in the almost 50 -cm-thick nannofossil layer (97 to $140 \mathrm{~cm}$ of Section 4), which displays an apparent upward decrease in grain size and color variations from pale yellowish brown to very pale orange. The bottom boundary is oblique and sharp against the underlying zeolitic clay while the top boundary is irregularly mottled. The lower half of this sequence is convoluted. According to the microscopic observation of the graded sequence, the lower half contains nearly 20 percent foraminifera tests while the upper half has less than 3 percent foraminifera. In addition to this, nannofossils of the lower part seem to make larger clusters or aggregates than those of the upper. Size grading is caused by these factors.

The top $7 \mathrm{~cm}$ of Section 5 is very pale brown foraminifera-bearing nannofossil turbidite. The rest of the section is wholly composed of dark brown clay with traces of nannofossils. The upper half of the clay is more or less mottled.

\section{Core 2 (67-76.5 Meters)}

This core is made up of middle Miocene (or ?younger) sediments together with reworked Eocene, Oligocene, and early Miocene elements. Sections 1 through 4 are composed of dark yellowish brown clay, which occasionally contains small fragments of plagioclase and sandy siltstone (or indurated silt) with abundant opaque components. Sections 5 and 6 of the core are made up of dark brown clay with varying amounts of displaced nannofossils, which are intercalated with two thin layers $(2 \mathrm{~cm}$ and $5 \mathrm{~cm})$ of dusky brown laminated siltstone (or indurated silt) at the lower part of Section 6. Additionally, some patches of grayish orange nannofossil ooze are found in Section 5, and a few chips or lumps of dusky brown laminated siltstone are scattered near the siltstone layers of Section 6. This siltstone, either fragmental or layered, contains abundant to common grains of feldspar, light glass shards, pyroxene, iron opaques, and rare nannofossils.

\section{Core 3 (76.5-86 Meters)}

The core is middle Miocene (or ?younger) in age. It contains reworked Eocene-Oligocene to ?early Miocene material. The sediments were fully recovered except for Section 1, which shows only 20 percent recovery. The sediment is almost entirely a moderate yellowish brown clay with traces of nannofossils. Pebble-sized fragments and small patches of dusky brown feldspathic silt are occasionally found in the core. One of them shows excellent cross-lamination.

\section{Core 4 (86-95.5 Meters)}

Sections 1 through 5 of this core show 90 percent recovery and contain middle Miocene (or ?younger) sediments with reworked ?Eocene-Oligocene to ?early 


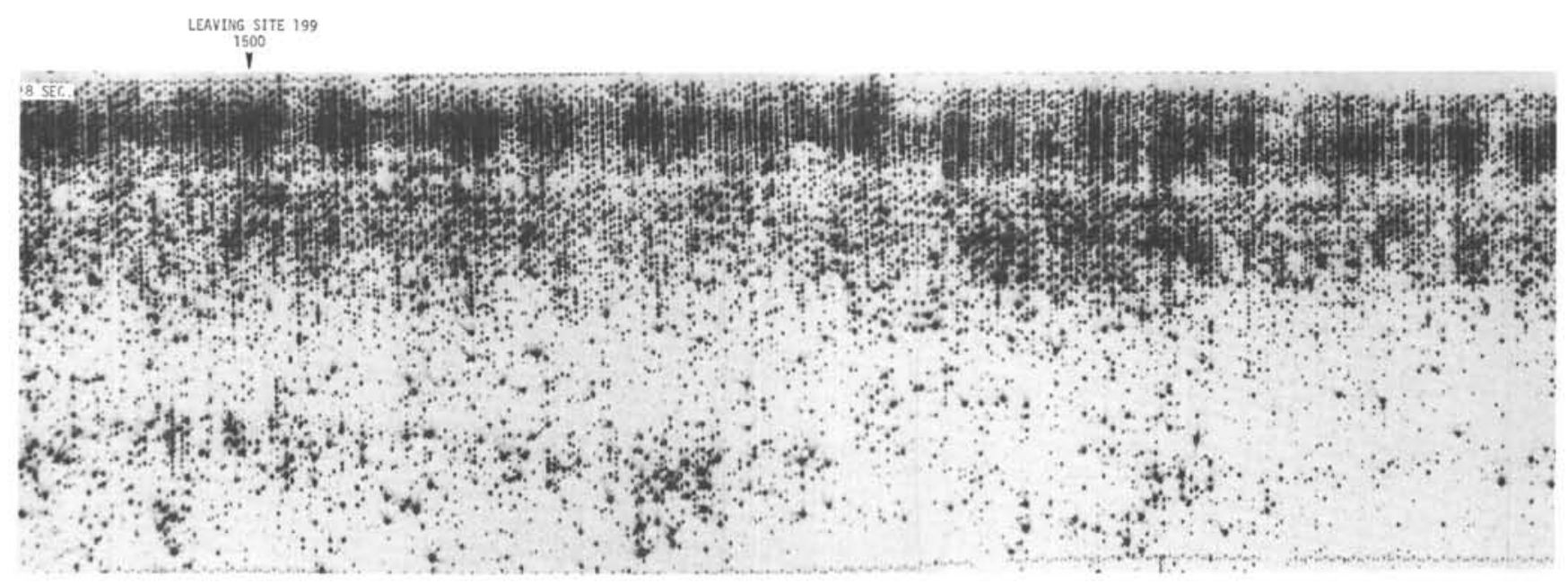

Figure 4. Glomar Challenger seismic profile across Site 199 leaving site.

Miocene components. The sediment is almost wholly composed of moderate yellowish brown silty clay with traces of nannofossil remains. In Section 5 occurs a $10-\mathrm{cm}$-thick olive gray silt layer which contains abundant plagioclase and zeolites and common to rare glass shards, palagonite, and nannofossils. Section 4 shows abundant parallel laminations.

\section{Core 5 (143-152.5 Meters)}

The entire length of the recovered core is made up of dark yellowish brown to very dark grayish brown, homogeneous radiolarian ooze. Throughout the core, well-preserved radiolarians (reworked; earliest Eocene to late early Miocene age) and their test fragments are abundant and are more or less filled with brown clay minerals. Sections 1 and 2 occasionally contain small fragments of calcareous nannoplankton ooze and/or bluish gray to light brown clay with traces of nannofossils (about $1 \times 2 \mathrm{~cm})$.

\section{Core 6 (200-209.5 Meters)}

This core consists of middle Miocene (or ?younger) sediments with reworked late or middle Eocene-Oligocene components. The upper half of Section $1(10-74 \mathrm{~cm})$ is a

TABLE 1

Coring Summary, Site 199

\begin{tabular}{|c|c|c|c|c|c|c|c|c|c|c|c|}
\hline \multirow[b]{2}{*}{ Core } & \multirow{2}{*}{$\begin{array}{l}\text { Date } \\
\text { (Sep) }\end{array}$} & \multirow[b]{2}{*}{ Time } & \multicolumn{2}{|c|}{$\begin{array}{l}\text { Subbottom } \\
\text { Depth }(m)\end{array}$} & \multicolumn{2}{|c|}{ Total Depth (m) } & \multirow{2}{*}{$\begin{array}{c}\text { Cored } \\
(\mathrm{m})\end{array}$} & \multirow[b]{2}{*}{ Recovered } & \multirow[b]{2}{*}{ Age } & \multirow[b]{2}{*}{ Lithology } & \multirow[b]{2}{*}{ Paleontology } \\
\hline & & & Top & Bottom & Top & Bottom & & & & & \\
\hline 1 & 23 & 2100 & 57.5 & 67.0 & 6157.5 & 6167.0 & 9.5 & $7.0 \mathrm{~m}$ & E. Pliocene & $\begin{array}{l}\text { Yellowish gray nanno- } \\
\text { fossil ooze and brown } \\
\text { zeolitic clay }\end{array}$ & Nannoplankton \\
\hline 2 & 23 & 2315 & 67.0 & 76.5 & 6167.0 & 6176.5 & 9.5 & $9.5 \mathrm{~m}$ & M. Miocene & Brown, silty zeolitic clay & Nannoplankton \\
\hline 3 & 24 & 0120 & 76.5 & 86.0 & 6176.5 & 6186.0 & 9.5 & $6.5 \mathrm{~m}$ & M. Miocene & Brown, silty zeolitic clay & Nannoplankton \\
\hline 4 & 24 & 0300 & 86.0 & 95.5 & 6186.0 & 6195.5 & 9.5 & $7.0 \mathrm{~m}$ & E. mid Miocene & Brown, silty zeolitic clay & Nannoplankton \\
\hline 5 & 24 & 0630 & 143.0 & 152.5 & 6243.0 & 6252.5 & 9.5 & $9.5 \mathrm{~m}$ & $\begin{array}{l}\text { L. Oligocene } \\
\text { or younger }\end{array}$ & Radiolarian ooze & Radiolaria \\
\hline 6 & 24 & 0945 & 200.0 & 209.5 & 6300.0 & 6309.5 & 9.5 & $7.5 \mathrm{~m}$ & M. Miocene & $\begin{array}{l}\text { Gray and brown zeolitic } \\
\text { clay }\end{array}$ & Nannoplankton \\
\hline 7 & 24 & 1600 & 285.5 & 295.0 & 6385.5 & 6395.0 & 9.5 & $1.5 \mathrm{~m}$ & L. Paleocene & Limestone/chert & Nannoplankton \\
\hline 8 & 24 & 1855 & 295.0 & 304.5 & 6395.0 & 6404.5 & 9.5 & $1.5 \mathrm{~m}$ & L. Paleocene & Limestone/chert & Nannoplankton \\
\hline 9 & 24 & 2200 & 304.5 & 314.0 & 6404.5 & 6414.0 & 9.5 & $2.5 \mathrm{~m}$ & L. Paleocene & Limestone/chert & Nannoplankton \\
\hline 10 & 25 & 0510 & 371.0 & 380.5 & 6471.0 & 6480.5 & 9.5 & $2.0 \mathrm{~m}$ & E. Paleocene & Limestone/chert & Nannoplankton \\
\hline 11 & 25 & 0830 & 399.5 & 409.0 & 6499.5 & 6509.0 & 9.5 & $3.0 \mathrm{~m}$ & E. Cret.-E. Tert. & Limestone/chert & Nannoplankton \\
\hline 12 & 25 & 1230 & 437.5 & 447.0 & 6537.5 & 6547.0 & 9.5 & $1.0 \mathrm{~m}$ & L. Campanian & Chalk, brown clay, chert & Nannoplankton \\
\hline 13 & 25 & 1940 & 447.0 & 456.5 & 6547.0 & 6556.5 & 9.5 & $0.5 \mathrm{~m}$ & - & Brown tuf & \\
\hline
\end{tabular}

Note: The mud line is at 6100 meters. 


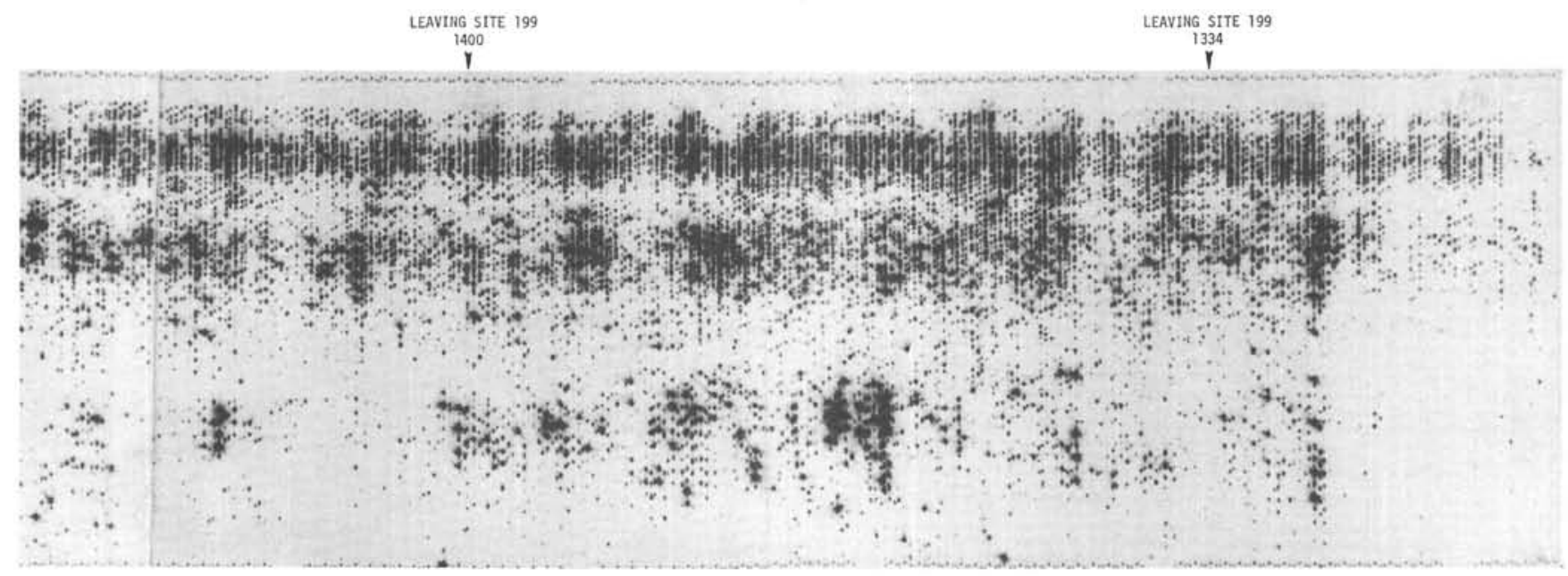

Figure 4. (Continued).

TABLE 2

Lithologic Units, Site 199

\begin{tabular}{|c|c|c|c|}
\hline Unit & Core Horizon & $\begin{array}{l}\text { Estimated } \\
\text { Thickness } \\
\text { (m) }\end{array}$ & Lithology \\
\hline A & Core 1 (Sections 1-4) & 5 & $\begin{array}{l}\text { Alternations of dark } \\
\text { brown clay and nanno- } \\
\text { fossil turbidites }\end{array}$ \\
\hline B & $\begin{array}{l}\text { Core } 1 \text { (Section } 5) \text {, } \\
\text { Cores } 2,3 \text {. }\end{array}$ & 17 & Dark brown clay \\
\hline C & Core 4 & $7^{\mathrm{a}}-54.5^{\mathrm{b}}$ & $\begin{array}{l}\text { Moderate brown silty } \\
\text { clay }\end{array}$ \\
\hline D & Core 5 & $9.5^{\mathrm{a}}-104.5^{\mathrm{b}}$ & $\begin{array}{l}\text { Dark brown radiolarian } \\
\text { ooze }\end{array}$ \\
\hline $\mathrm{E}$ & Core 6 (Sections 1-2) & $3^{\mathrm{a}}-50.5^{\mathrm{b}}$ & $\begin{array}{l}\text { Interlayered tuff, } \\
\text { nannofossil-rich clay, } \\
\text { and silty clay }\end{array}$ \\
\hline $\mathrm{F}$ & Core 6 (Sections $3-4$ ) & $4.5^{\mathrm{a}}-80.5^{\mathrm{b}}$ & Silty ash \\
\hline G & Cores 7-9 (Section 1) & $3.8^{\mathrm{a}-79.8^{\mathrm{b}}}$ & $\begin{array}{l}\text { Nannochalk with chert } \\
\text { partings }\end{array}$ \\
\hline $\mathrm{H}$ & $\begin{array}{l}\text { Core } 9(\text { Section } 2) \text {, } \\
\text { Cores } 10-13\end{array}$ & $61.5+$ & $\begin{array}{l}\text { Interlayered nanno- } \\
\text { chalk, limestone, tuff, } \\
\text { and chert }\end{array}$ \\
\hline
\end{tabular}

Note: Base of sequence not cored.

aBased on recovered sediments thickness.

bextrapolated maximum thickness.

dark gray, sandy to silty tuff in which dark-colored pebble-sized shale clasts occur, except between 70 to 74 $\mathrm{cm}$. This layer possesses a sharp lower boundary and is parallel-laminated at the bottom $4 \mathrm{~cm}$ and then gradually becomes coarser upward with shale chips. The lower half of Section 1 is mainly a yellowish brown nannofossil-rich clay. Between these two beds intervenes a 4-cm-thick layer of grayish olive, nannofossil-bearing clay.

The primary sedimentary structures evident in the tuff layer suggests the existence of bottom currents at the time of deposition.
Section 2 can be divided into three layers. The upper one $(0-45 \mathrm{~cm})$ consists of moderate yellowish brown nannofossil-rich clay with rare glass shards, zeolite, and limonitic minerals. The middle layer $(45-103 \mathrm{~cm})$ is grayish blue green nannofossil-bearing silty ash. Opaque minerals are most abundant in the lower layer.

The sediment of Sections 3 through 5 is a grayish blue green silty ash with small and varying amounts of nannofossils. Glass shards of silt size are dominant. Also present are smaller amounts of palagonite, carbonates, pyroxene, and opaque minerals. These sections are middle Miocene or younger in age and contain reworked late or middle Eocene to Oligocene organisms.

\section{Core 7 (285.5-295 Meters)}

The upper $100 \mathrm{~cm}$ consists mainly of pale orange late Paleocene nannofossil chalk showing very weak lamination. Near the top occur very thin layers of dark yellowish brown chert. Several chips of yellowish brown chert were obtained below this chalk.

\section{Core 8 (295-304.5 Meters)}

The core consists of white to very pale orange late Paleocene nannofossil chalk with faint laminations. Amongst the pieces of chalk are found smaller chips of yellowish brown to grayish brown chert. Only one piece shows a flat contact between chert and chalk.

\section{Core 9 (304.5-314 Meters)}

In Section 1, from $70 \mathrm{~cm}$ to $150 \mathrm{~cm}$, the sediment consists of pieces of late Paleocene chalk, chert, and siliceous limestone. The chalk is moderate orange pink to pale yellowish brown in color and is finely laminated in the upper part, whereas, it is white and massive in the lower part. The chert is moderate brown to dusky brown in color and occupies minor portions of the section.

Section 2 is composed mainly of light gray to white, late Paleocene nannofossil chalk and, subordinately, of very 


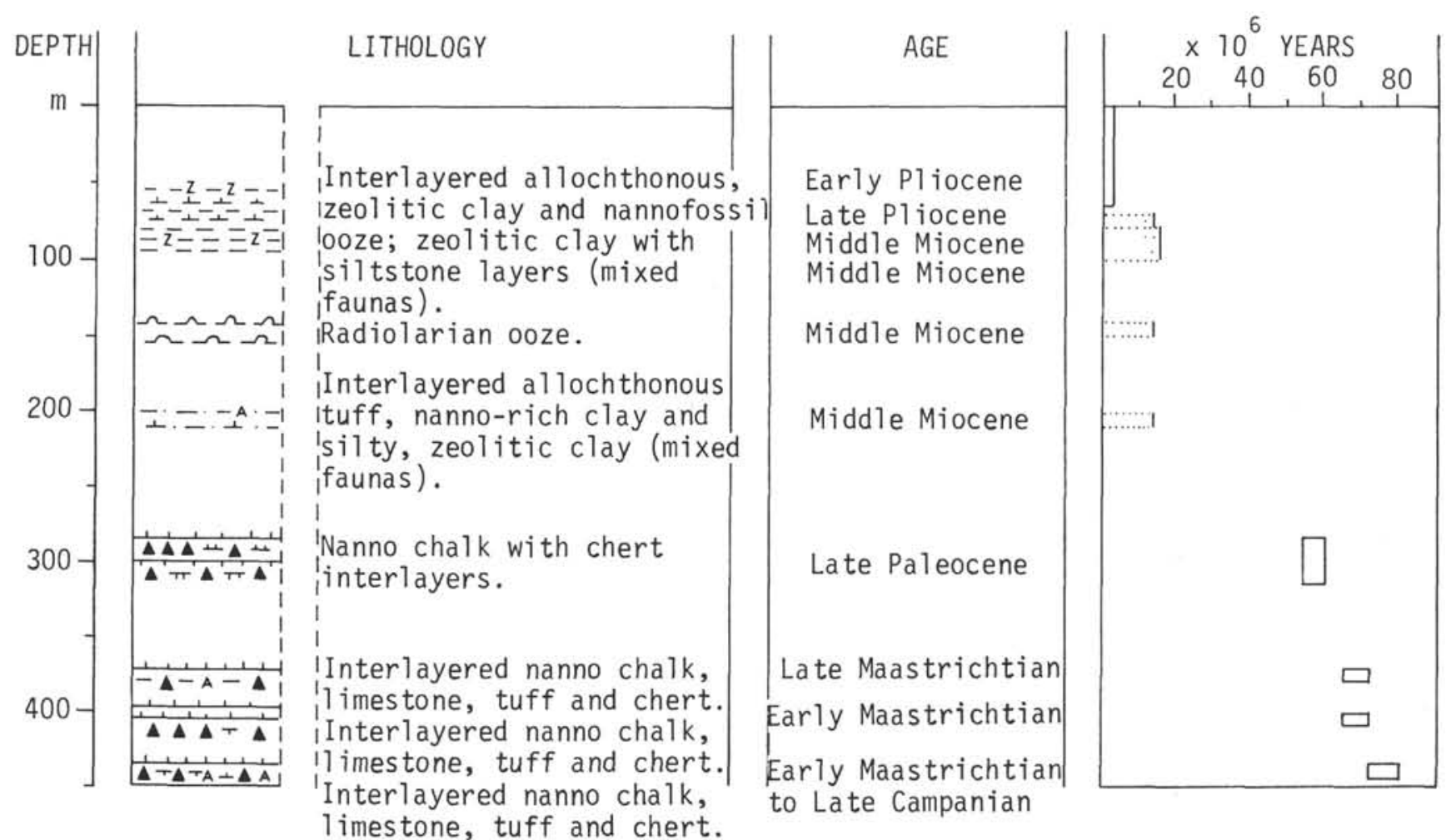

Figure 5. Stratigraphy of Site 199.

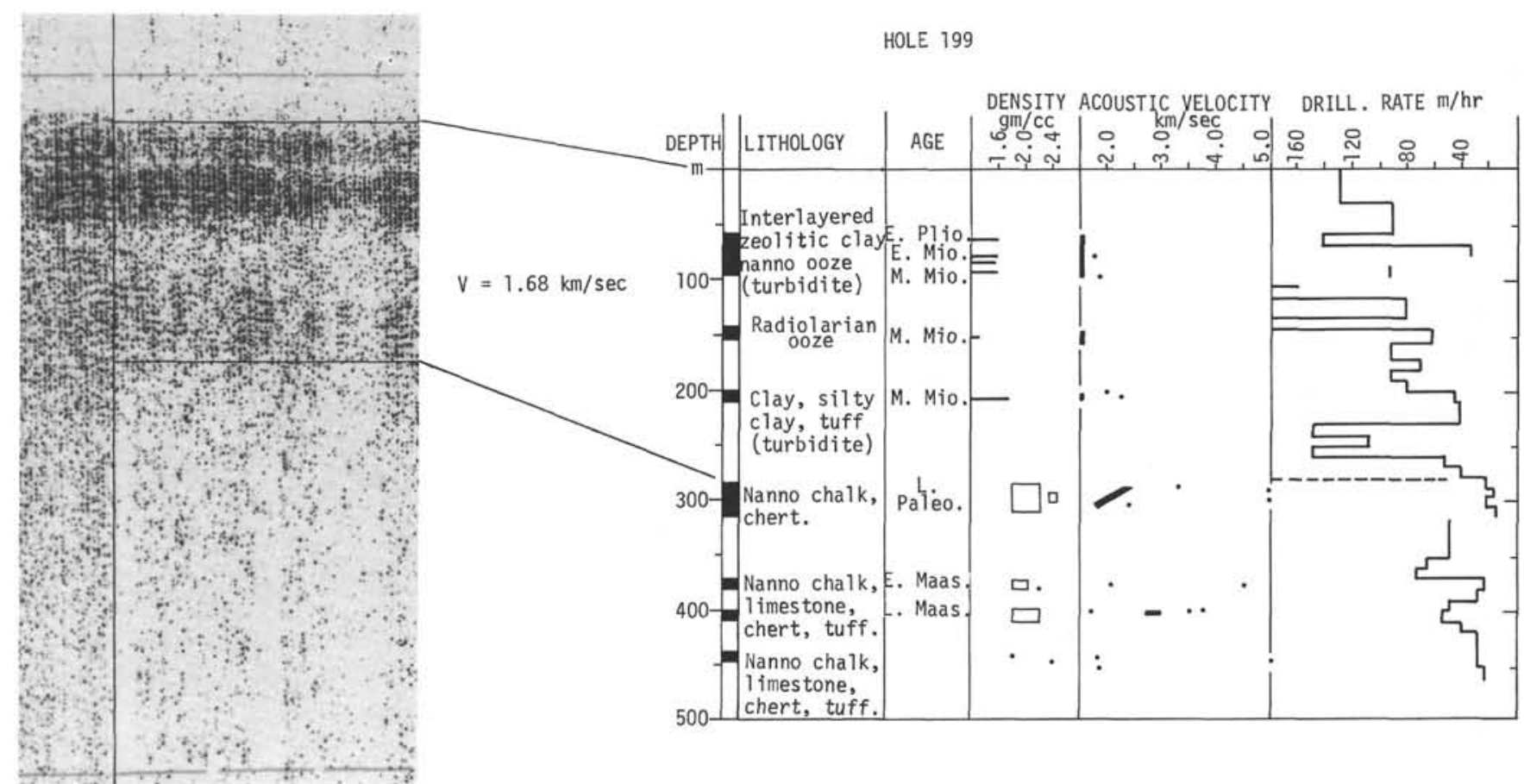

Figure 6. Correlation of drilled record at Site 199 with seismic profile. 
pale brown nannofossil limestone. The chalk is partly weakly laminated and sometimes accompanied by brown chert irregular in form. The chalk grades downwards into massive limestone.

\section{Core 10 (371-380.5 Meters)}

The recovered sediments mostly comprise white to very pale brown, massive, nannofossil chalk. Thin layers of brownish chert, pale blue green to grayish brown tuff, and limestone are interbedded at the middle part of Section 2 $(46-60 \mathrm{~cm})$. The tuff is composed of abundant glass shards and zeolites with traces of nannofossils. Section 1 and Section 2 down to $40 \mathrm{~cm}$ is late Paleocene in age. Then there is a gap in sedimentation of about 4 m.y. duration. The sequence below $60 \mathrm{~cm}$ of Section 2 is of early Paleocene-Danian age.

\section{Core 11 (399.5-409 Meters)}

The succession is made up of interlayered nannofossil chalk, limestone, siliceous limestone, chert, tuff, and nannofossil ooze, of which the first three lithologies are present in fairly thick layers (more than $15 \mathrm{~cm}$ ). The chalk is very pale brown to light yellowish brown and massive and contains small amounts of foraminifera. The siliceous limestone is moderate orange pink to yellowish gray in color, massive and may be weakly laminated, and grades in to the other lithologies. The chert is brownish and more or less laminated and some is nodular in shape. Tuff layers, found only in Section 2, are reddish brown to very dark gray, and show no internal structure. Small amounts of zeolite and nannofossils are contained in the tuff. The nannofossil ooze, which is found only in Section 1, is light greenish in color and about $10 \mathrm{~cm}$ thick. Section 1 is early Paleocene-Danian in age. The core catcher of Section 2 is of late Maastrichtian age.

\section{Core 12 (437.5-447 Meters)}

The sediment consists mainly of pinkish white late Campanian-early Maastrichtian nannofossil chalk in which small nodules of brown chert are distributed. This chalk is capped by at least a $5-\mathrm{cm}$-thick, reddish brown zeolitic tuff layer with sinall amounts of nannofossils. The boundary between the tuff layer and the underlying chalk is partly sharp but mostly gradational. A 2-cm-long burrow extends obliquely downwards from the tuff layer.

\section{Core 13 (447-456.5 Meters)}

Only a core catcher sample was obtained. The sediment is a brown zeolitic tuff composed almost exclusively of glass shards.

\section{BIOSTRATIGRAPHIC SUMMARY}

Biogenic components found in Site 199 cores are summarized as follows:

\section{Core 1:}

Foraminifera: Mixture of Oligocene and Miocene foraminifera-Pseudohastigerina barbadoensis, Chilogümbelina cubensis, Globigerina angulisuturalis, G. ouachitaensis, G. praebulloides, G. prasaepis, Cassigerinella chipolensis,
Globigerina bradyi, G. juvenilis, G. foliata, Globorotalia acostaensis, G. miocenica, G. merotumida, G. menardii, Globigerina nepenthes. The age of turbidites is not older than the upper Miocene (Tortonian stage).

Nannofossils: Mixture of nannofossils of different ages. The youngest age represented is the early PlioceneDiscoaster asymmetricus Zone with the typical species, abundant Sphenolithus abies, few Ceratolithus rugosus, C. tricorniculatus and C. amplificus. Reworked nannofossils of Eocene to Oligocene age (Dictyococcities scrippsae, Reticulofenestra umbilica) Discoaster barbadiensis and of late Miocene age (Discoaster quinqueramus, Discoaster berggrenii) are present.

Foraminifera: Only very rare, very poor indeterminate Radiolaria.

\section{Core 2:}

Foraminifera: none.

Nannofossils: Mixture of nannofossils. The Catinaster coalitus Zone from the middle Miocene is represented by the typical species. No younger elements have been observed. Cyclicargolithus floridanus and Discoaster deflandrei represent derived early Miocene. Dictyococcites bisectus represents reworked Eocene or Oligocene. Other Miocene species include Reticulofenestra pseudoumbilica, Discoaster variabilis and Sphenolithus abies.

Radiolaria: Only very rare, very poor, indeterminate Radiolaria.

\section{Core 3:}

Foraminifera: Mixture of foraminifera of different ages: lower Eocene - Globorotalia wilcoxensis; upper Eocene - Globorotalia cerroazulensis; Oligocene - Globorotalia opima opima; and Miocene - Globorotalia acostaensis, G. menardii, G. miocenica, G. lenguaensis, G. peripheroacuta, G. obesa, Candeina nitida praenitida, Globigerina nepenthes, G. bulbosa, Sphaeroidinellopsis subdehiscens, Orbulina suturalis, $O$. universa, Praeorbulina bilobata. Miocene species strongly predominate. The age of turbidites is not older than the late Miocene (Tortonian stage).

Nannofossils: Mixture of nannofossils of different ages. The youngest elements are Cycloccolithina leptopora and Discoaster variabilis from the Miocene. The following reworked forms are found: Dictyococcites bisectus, $D$. scrippsae and D. abisectus.

Radiolaria: In section 5 only very rare, poor Cyrtocapsella cornuta, Stichocorys delmontensis and $S$. wolffii, indicating an early to middle Miocene age.

\section{Core 4:}

Foraminifera: none.

Nannofossils: Mixture of nannofossils of different ages. The youngest elements are Discoaster kugleri and Discoaster exilis from the middle Miocene. The following reworked forms are found: Dictyococcites bisectus, Dictyococcites scrippsae, Reticulofenestra umbilica (Eocene or Oligocene): Dictyococcites abisectus (Oligocene or early Miocene); Sphenolithus belemnos (early Miocene). 
Radiolaria: Only very rare, very poor, indeterminate Radiolaria.

\section{Core 5:}

Foraminifera: none.

Nannofossils: Out of five samples examined, four were barren and the remaining one contains a few specimens from the Sphenolithus heteromorphus Zone including: Cyclicargolithus floridanus, Discoaster deflandrei, Reticulofenestra pseudoumbilica, and Sphenolithus heteromorphus. These are obviously reworked because of the younger age indication in Core 6.

Radiolaria: Well preserved abundant Radiolaria are mixed. The youngest forms, which must be considered reworked, are throughout the core: Lithocyrtis angustum, Dorcadospyris ateuchus, and Cyclampterium pegetrum, and in the lower half of the core, are Dorcadospyris circulus and Cannartus prismaticus. Older forms are present from the late Paleocene-middle Eocene. Forms from the late Eocene and much of the early Oligocene are missing.

\section{Core 6:}

Foraminifera: Assemblages of planktonic foraminifera in turbidites represent mixture of reworked species of Oligocene (P.19-P.21), lower Miocene (N.4), and middle-upper Miocene: Pseudohastigerina barbadoensis, Chilogümbelina cubensis, Globorotalia opima opima, G. pseudokugleri, G. kugleri, Globigerina bradyi, $G$. juvenilis, Globoquadrina dehiscens, G. altispira, Globorotalia siakensis, Sphaeroidinellopsis seminulina, and Orbulina suturalis. The age of turbidites is not older than middle Miocene.

Nannofossils: This core contains predominantly EoceneOligocene species: (Ceratolithina? vesca, Discoaster barbadiensis, Dictyococcites bisectus, Chiasmolithus grandis, and Sphenolithus predistentus). Only the rare occurrence of questionable Discoaster bollii could indicate a middle Miocene age.

Radiolaria: Very rare, poor Stichocorys delmontensis and $S$. wolffii indicating an early to middle Miocene age.

\section{Core 7:}

Foraminifera: none (hard limestone).

Nannofossils: The late Paleocene nannofossil assemblage consists of Discoaster multiradiatus, Fasciculithus involutus, $F$. aff. mitreus, Toweius eminens and Coccolithus cavus. The occurrence of Discoaster mohleri in considerable numbers may indicate reworking of early Paleocene. Watznaueria barnesae, Micula mura, $M$. decussata, and Cretarhabdus surirellus are reworked Cretaceous fossils.

Radiolaria: none.

\section{Core 8:}

Foraminifera: Throughout Section 1, the assemblages of planktonic foraminifera consist of numerous Globorotalia velascoensis, $G$. velascoensis parva, $G$. imitata, $G$. trichotrocha, $G$. acuta, $G$. laevigata, $G$. occlusa, $G$. aequa, G. hispidicidaris, Acarinina acarinata, A. mckannai, $A$. primitiva, A. strabocella, A. soldadoensis, $A$. esnaensis, and Globigerina nana. Upper Paleocene, the Globorotalia velascoensis Zone. Preservation of shells in hard limestones is very often bad. Reworked big Maastrichtian species of Globotruncana, Rugoglobigerina, etc. are common.

Nannofossils: The late Paleocene nannofossil assemblage consists of Discoaster multiradiatus, Fasciculithus spp., Toweius eminens, and common Coccolithus cavus. Reworked Cretaceous fossils appear in considerable numbers (Watznaueria barnesae, Micula decussata, and Cretarhabdus surirellus). Discoaster gemmeus indicates reworking of early Paleocene.

Radiolaria: Very rare, poor reworked Cretaceous Radiolaria.

\section{Core 9:}

Foraminifera: A core catcher is characterized by microfauna of bad preservation-Globorotalia velascoensis, $G$. occlusa, $G$. acuta, $G$. laevigata, $G$. apanthesma, $G$. hispidicidaris, $G$. imitata, Acarinina acarinata, $A$. mckannai, A. primitiva. Upper Paleocene; the Globorotalia velascoensis Zone. Reworked species of Maastrichtian Abathomphalus, Globotruncana, Rugoglobigerina, Heterohelix, etc. are common. Sections 1 and 2 do not contain foraminifera.

Radiolaria: none.

\section{Core 10:}

Foraminifera: Assemblages of planktonic foraminifera of Section 2 (in interval $0-38 \mathrm{~cm}$ ) consist of numerous Globorotalia occlusa together with subordinate $G$. laevigata, G. pseudomenardii, $G$. velascoensis parva, $G$. imitata, $G$. convexa and reworked big Maastrichtian Globotruncana, etc. Upper Paleocene, the Globorotalia pseudomenardii Zone.

The lower part of Section 2 (in the interval 58-145 $\mathrm{cm}$ ) and a core catcher contain comparatively rare minute "Globigerina" eugubina, " $G$." fringa, " $G$." minutula, "G." sabina, "G." anconitana, Chilogümbelina taurica, Gümbelitria irregularis and reworked (?) small Rugoglobigerina, etc. It is the "Globigerina" eugubina Zone, the age of which is disputable-either the topmost Maastrichtian or basal Danian (Paleocene).

Nannofossils: Section 1 and Section 2 down to $40 \mathrm{~cm}$ still contain nannofossils of the Discoaster multiradiatus Zone. With a change in lithology, a major time break can be observed. Section 2, below $60 \mathrm{~cm}$, contains a majority of reworked late Cretaceous fossils, however, they contain also the Danian or earlier Paleocene forms Cruciplacolithus tenuis and Coccolithus cavus. The reddish stained cross-laminated chalk between 40 and 60 $\mathrm{cm}$ represents sedimentation over $5 \mathrm{~m} . \mathrm{y}$. and contains a late Cretaceous assemblage without any Paleocene element. It obviously consists entirely of reworked sediments.

Radiolaria: Only very rare, very poor indeterminate Radiolaria.

\section{Core 11:}

Foraminifera: Assemblages of planktonic foraminifera determine the age of sediments as the uppermost part of 
the Maastrichtian and, evidently, the lowermost part of the Danian stage (Paleogene).

Section $1(52-53,97-98,132-133,143-145 \mathrm{~cm})$ is characterized by minute "Globigerina" eugubina, "G." minutula, Gümbelitria sp., small reworked(?) Rugoglobigerina spp., Pseudogümbelina spp. and belongs to the topmost Maastrichtian or the base of the Danian stage (the "Globigerina" eugubina Zone).

Section 2 (0-2, 14-15, 43-44, 64-65, 103-104 cm) contains rare, small Abathomphalus mayaroensis, Globotruncanella havanensis, $G$. petaloidea, Hedbergella monmouthensis, Rugoglobigerina hexacamerata, Heterohelix striata and belongs to the upper Maastrichtian, the Abathomphalus mayaroensis Zone.

Nannofossils: Section 1, at $93 \mathrm{~cm}$, still contains the Danianearly Paleocene forms Coccolithus cavus and Cruciplacolithus tenius. In Section 2, $68 \mathrm{~cm}$, and in the core catcher sample, however, a pure Maastrichtian assemblage is found with Arkhangelskiella cymbiformis, Micula decussata, Cylindralithus gallicus, and Micula mura; the last species indicating the Micula mura Zone of the late Maastrichtian.

Radiolaria: none.

\section{Core 12:}

Foraminifera: Very rare, small Rugoglobigerina spp., Pseudogümbelina spp., Heterohelix sp. of bad preservation. The age of sediments can be determined in the limits of the Maastrichtian-Campanian stages.

Nannofossils: The coccoliths recovered from the core catcher sample indicate the Tetralithus trifidus Zone with the typical species and Broinsoina parca, representing the late Campanian to earliest Maastrichtian interval. The sample from Section 1, at $115 \mathrm{~cm}$, may represent a higher part of this zone as indicated by the appearance of large forms of Arkhangelskiella cymbiformis. Other typical forms are: Microhabdulus decoratus, Cylindralithus crassus, Cribrosphaerella ehrenbergii, and Cretarhabdus surirellus.

Radiolaria: none.

\section{Core 13:}

Foraminifera: none.

Nannofossils: none.

Radiolaria: none.

\section{PHYSICAL PROPERTIES}

Bulk density measurements were made on core sections and individual samples by GRAPE, syringe, and water displacement methods. In contrast to the situation at previous sites of Leg 20, the samples available for testing from Site 199 give a rather detailed section down to 450 meters subbottom depth. Results of bulk density and sonic velocity measurements are given in Figures 7 and 8 .

From 50 to 100 meters depth, the clays with their included clasts have a low average density but with quite large variation, due to the presence of the clasts. Since these clasts are rather small, the average densities recorded by the GRAPE cannot accurately show their separate density, although trends on the record are obvious. This reasoning is supported by the higher density of one clast which was

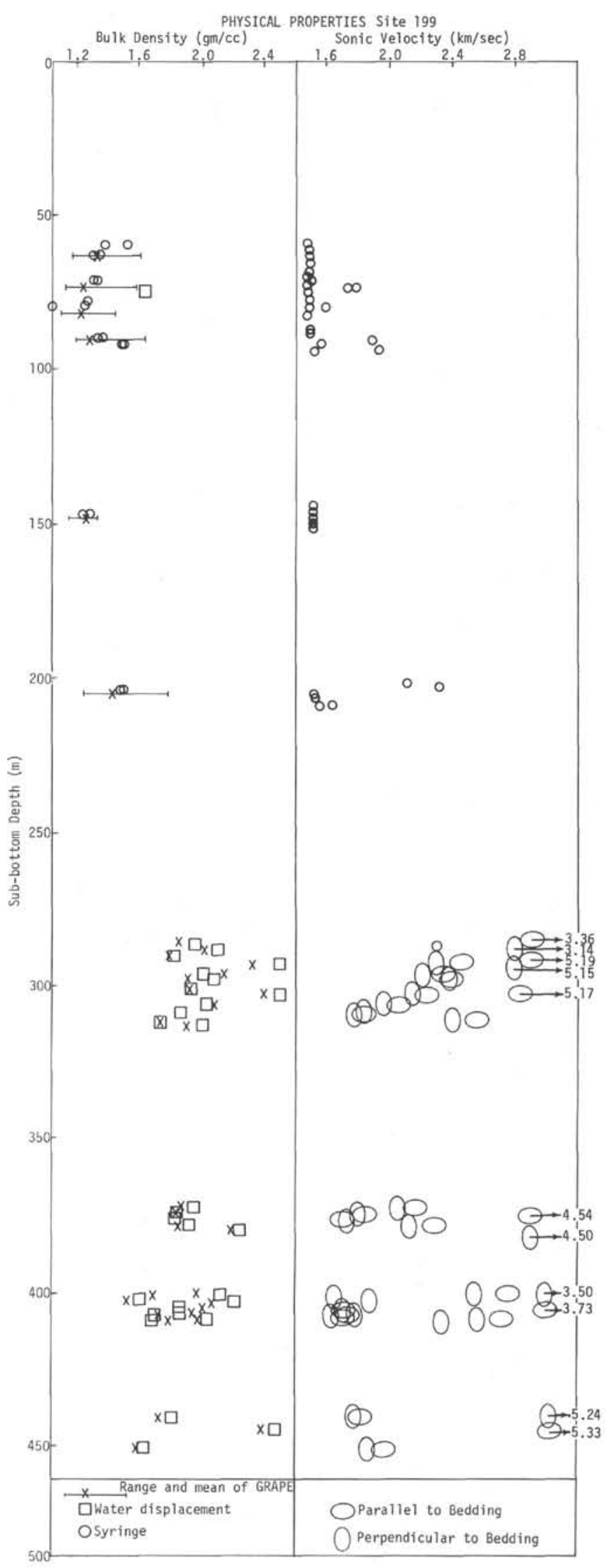

Figure 7. Measured values of bulk density and compressional sonic velocity vs. depth below sea floor at Site 199. 


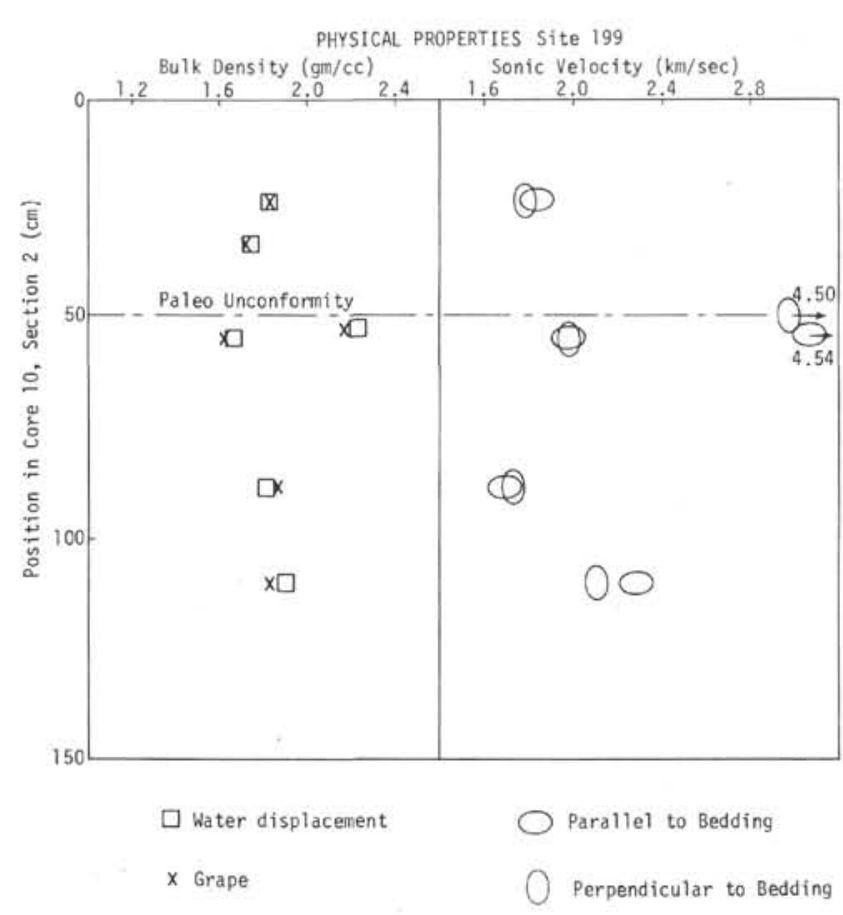

Figure 8. Measurements of bulk density and compressional sonic velocity in Core 10, Section 2, Site 199.

large enough for a water displacement density measurement.

The section at 150 meters depth is also of low density but much more homogeneous. At 200 meters, we again see scattered lumps with densities up to $1.8 \mathrm{gm} / \mathrm{cc}$ on the GRAPE device. Below 280 meters, the section consists of interbedded chalk, limestone, chert, and tuff with moderate to high densities. Any general trends or averages must be considered speculative, partly because of the scatter of the data and partly because the recovery (although good for this type of formation) was still quite low in an absolute sense. However, one can detect a slight decreasing density with depth trend from the graphical presentation. The last material recovered, a tuff from 450 meters, had a low density of $1.6 \mathrm{gm} / \mathrm{cc}$.

The sonic velocity measurements correlate well with the bulk density measurements. From 50 to 100 meters depth, velocities are about $1.5 \mathrm{~km} / \mathrm{sec}$ except in the clasts that first begin to appear at about 75 meters, which have belocities as high as $1.9 \mathrm{~km} / \mathrm{sec}$. This is clearly enough velocity contrast to provide reflectors on the profile record. We have previously remarked that the velocities measured in the laboratory for unconsolidated sediments could have been considerably lowered from in situ values by the obvious drilling disturbance. However, if the clasts of about 1.7 $\mathrm{km} / \mathrm{sec}$ velocity are to produce reflectors, the velocity of the unconsolidated sediments at this site could not have been lowered very much by this disturbance. No high velocity clasts are present in the core recovered from 150 meters, but clasts with velocities up to $2.2 \mathrm{~km} / \mathrm{sec}$ appear in the core from 200 meters. Here too, the velocities in the bulk of the core increase to slightly more than $1.6 \mathrm{~km} / \mathrm{sec}$.

The chalks and limestones from below 280 meters have moderate velocities with a large amount of variability between samples. Scattered layers of chert, with velocities averaging $5 \mathrm{~km} / \mathrm{sec}$, are interbedded with the chalks. Incomplete recovery makes it impossible to give an accurate average velocity for the section between 280 and 450 meters but an educated guess is about $2 \mathrm{~km} / \mathrm{sec}$. It was possible to examine a large number of samples for acoustic anisotropy, and a consistent pattern of about a five percent increase in velocity in the bedding plane was observed.

The thermal conductivity of two core sections was measured according to the procedures described in the summary for Site 198 , giving values of $1.78 \times 10^{-3} \mathrm{cal} /{ }^{\circ} \mathrm{C}$ $\mathrm{cm} \mathrm{sec}$ at 60 meters and 1.75 at 150 meters subbottom depth. These values fill in a blank square on the chart of $5^{\circ}$ $\times 5^{\circ}$ regions given by Langseth and von Herzen (1970), and are, interestingly, much lower than the high values recorded to the south of Site 199 .

\section{CONCLUSIONS}

The Caroline Abyssal Plain has existed since the mid Miocene. However, since Site 199 is located near the margin of the plain, it is conceivable that the plain is somewhat older and was only built out to this location by the mid Miocene. The few acoustic records from the abyssal plain are not easily correlated, and thus we cannot exclude a somewhat earlier age. Miocene is the presumed age of the Caroline Islands of Truk and Ponape, and Leg 6 recovered Miocene sediments lying over basalt on the western portion of the Caroline Ridge. Thus, the turbidites which contain fossils of Eocene through Miocene age could have been derived from the paroxysm which created the Caroline Ridge. The pelagic limestones of Upper Cretaceous to Paleogene age that underlie the turbidites represent mid-oceanic deposition at a considerably shallower depth with respect to the compensation depth as compared to the present abyssal depth. In the Maastrichtian, tuffs appear interbedded in the nannofossil limestones and the hole ended in tuff which is early Campanian or older. These tuffs apparently reflect nearby volcanism which might be assumed to be the volcanic episode which created the line of guyots and seamounts which lies north-northwest and south-southeast of the site. The seismic profiler record obtained after departing the site indicates at least 200 meters of sediment below the bottom of the hole. If carbonate rates of deposition of $10 \mathrm{~m} / \mathrm{m} . \mathrm{y}$. are assumed, the basement age would be 120 million years.

\section{REFERENCE}

Langseth, M. G. and von Herzen, R. P., 1970. Heat flow through the floor of the world oceans: The Sea, Maxwell, A. E. (Ed.), V. 4, p. 289-353. 


\begin{tabular}{|l|l|l|l|l|l|l|l|}
\hline Site 199 & & Hole \\
LITHOLOGIC OESCRIPTION
\end{tabular}

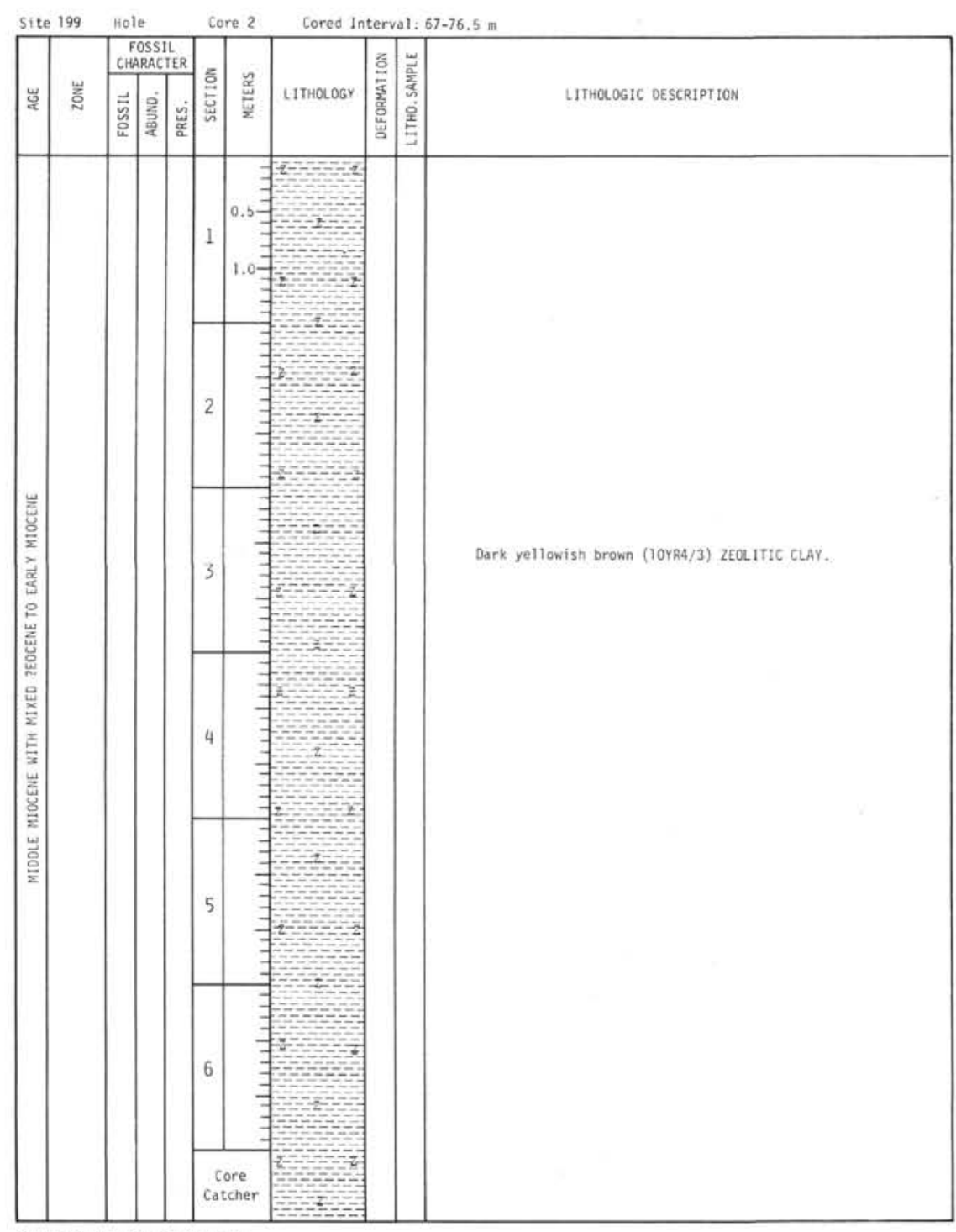

Explanatory notes in Chapter 1 
2

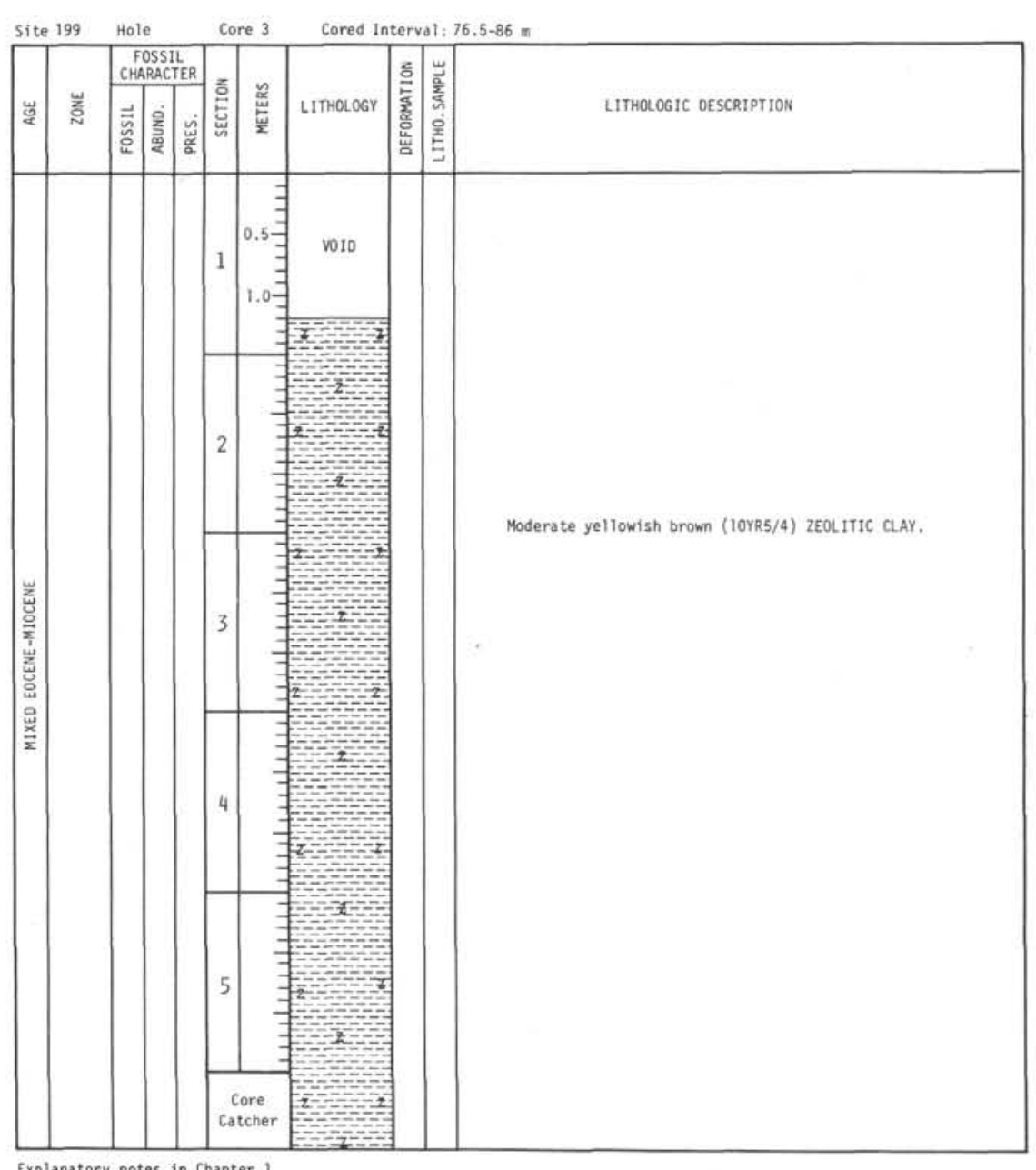

Explanatory notes in chapter

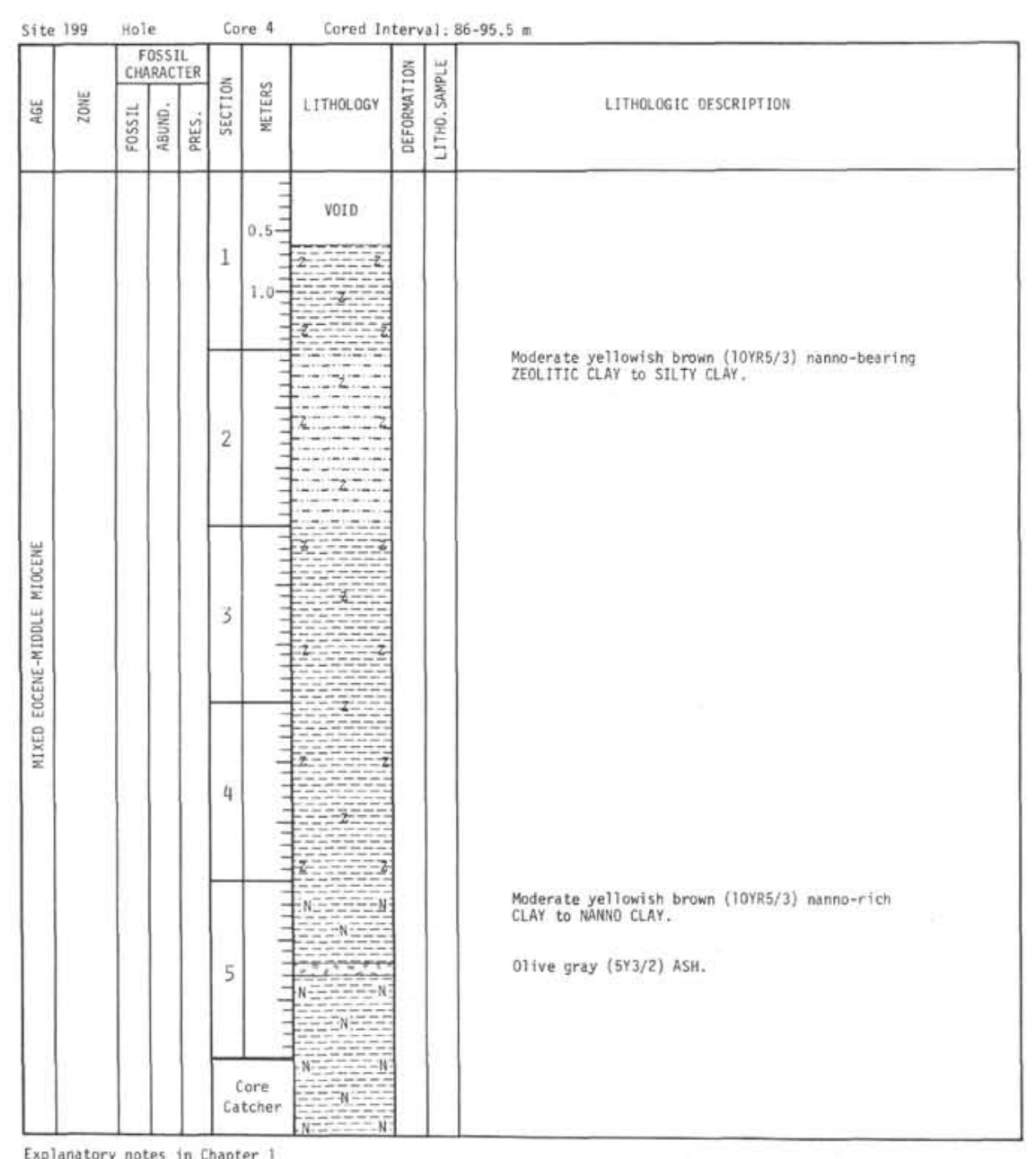

Explanatory notes in chapter 1 


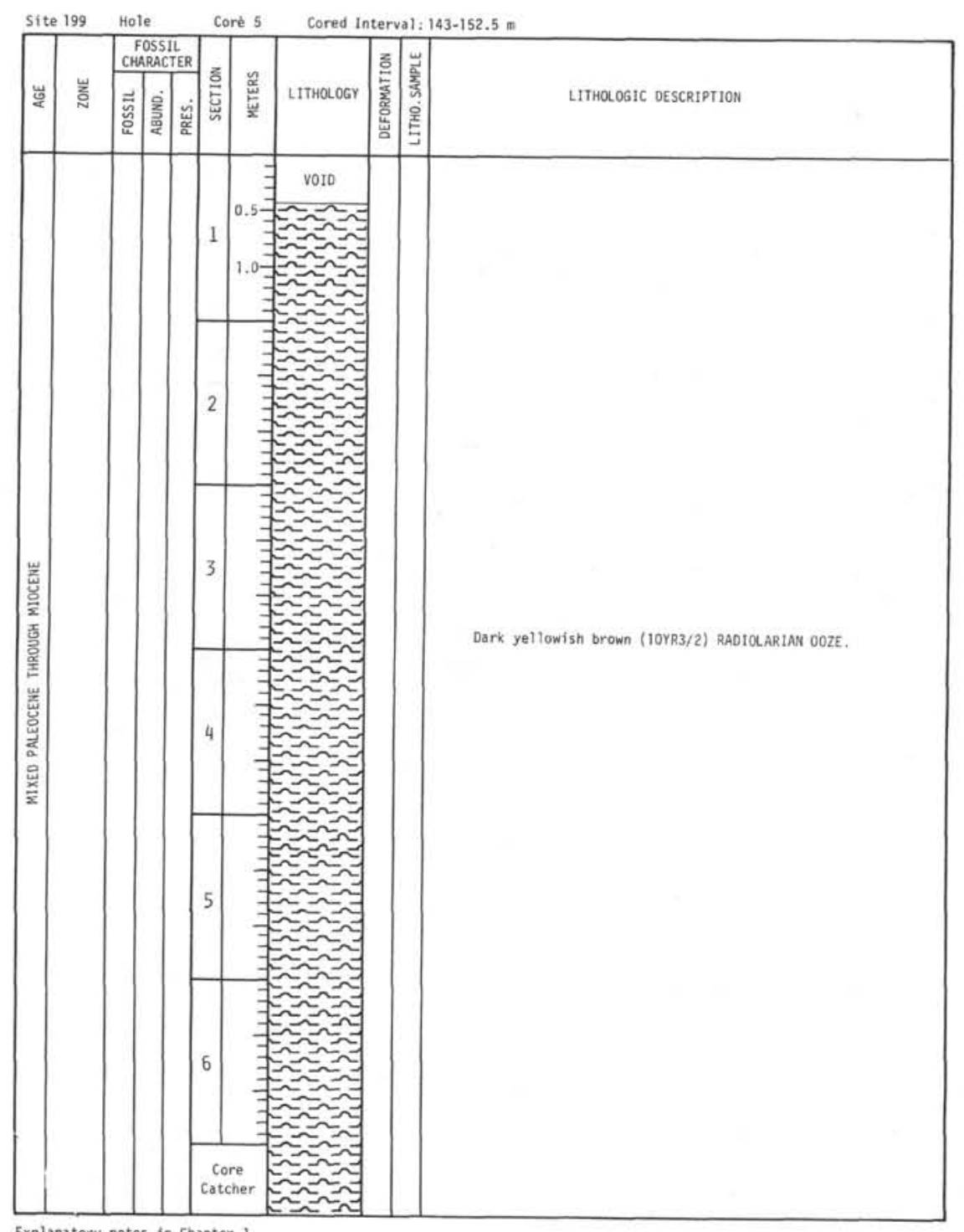

Explanatory notes in Chapter 1

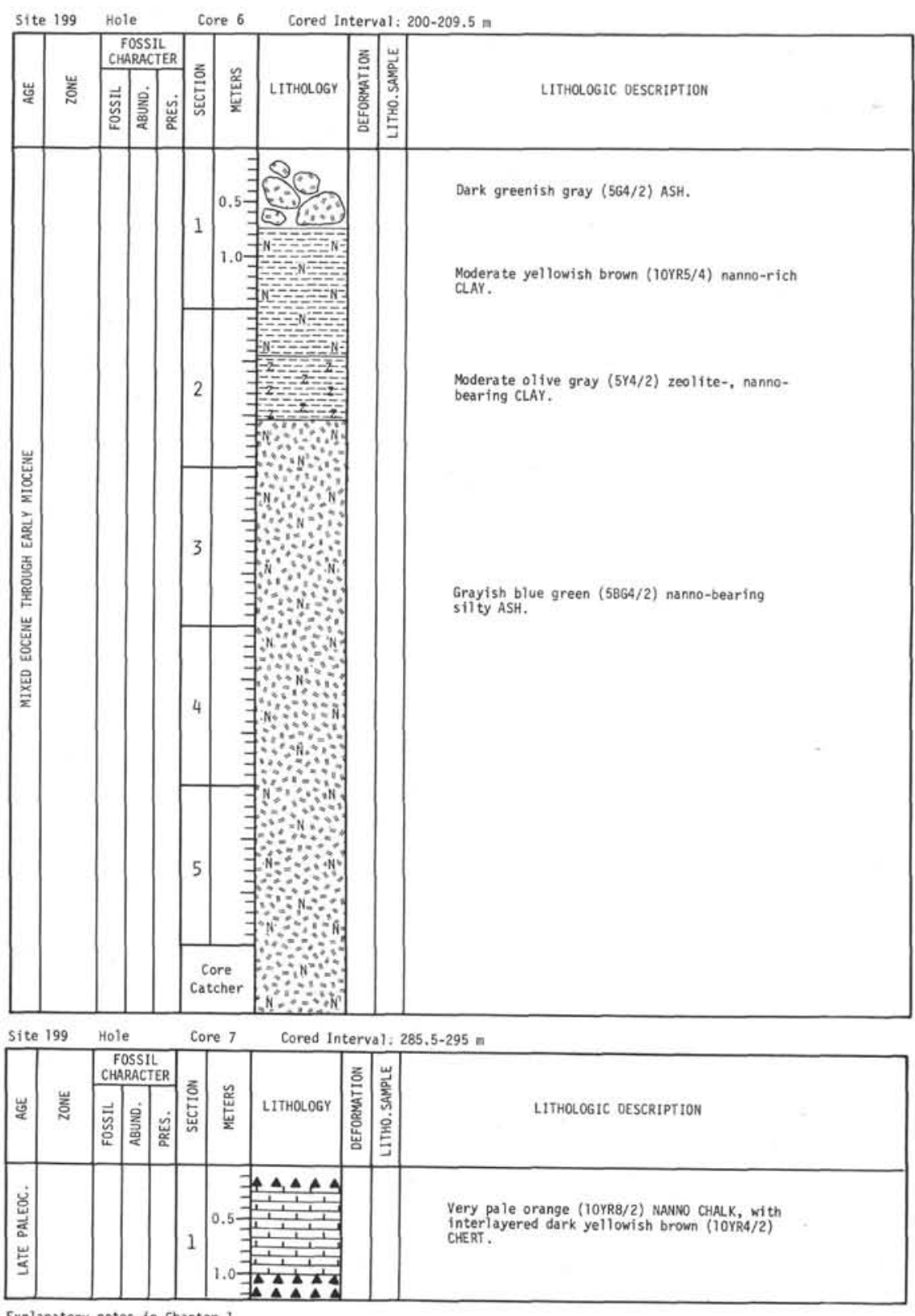

Explanatory notes in Chapter 


\begin{tabular}{|c|c|c|c|c|c|c|c|c|}
\hline \multicolumn{2}{|c|}{ Site 199} & \multicolumn{4}{|c|}{ Hole core 11} & \multicolumn{3}{|c|}{ Cored Interval: $399.5-409 \mathrm{~m}$} \\
\hline & & $\begin{array}{r}\text { FOSS } \\
\text { CHARA }\end{array}$ & & & & & 힘 & \\
\hline 岁 & 崖 & 苛 & $\dot{\vec{u}}$ & 불 & 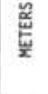 & LITHOLOGY & 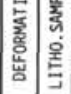 & LITHOLOGIC OESCRIPTION \\
\hline 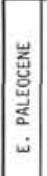 & 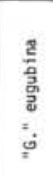 & & & 1 & $1.00 \frac{3}{3}$ & 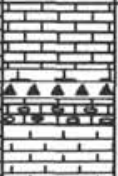 & & $\begin{array}{l}\text { Very pale brown LIMESTONE. } \\
\text { Light greenish (gray NANKO D0ZE. } \\
\text { Brownish gray (5YR4/1) CHERT. } \\
\text { Moderate orange pink (5YRB/4) to yellowish gray } \\
\text { (5Y8/1) SIL ICEOUS LIMESTONE. }\end{array}$ \\
\hline 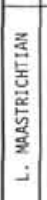 & 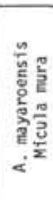 & & & 2 & & 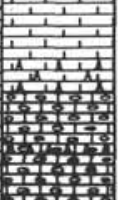 & & $\begin{array}{l}\text { Very pale brown (10YR8/3) NANNO CHALK, grading } \\
\text { down to StLICEOUS LIMESTONE assoctated with TUFF. }\end{array}$ \\
\hline
\end{tabular}

\begin{tabular}{|c|c|c|c|c|c|c|c|}
\hline & & Hole & & re 9 & Cored Inte & terval: 3 & $-314 \mathrm{~m}$ \\
\hline 冡 & 厗 & 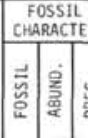 & 竞 & 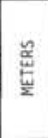 & LITHoL oG & 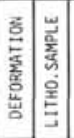 & LITHOLOGIC OESCRIPTION \\
\hline 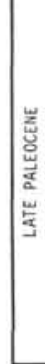 & 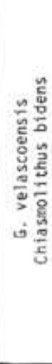 & & 2 & & 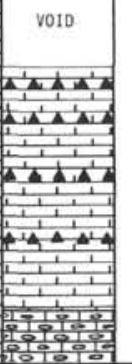 & & 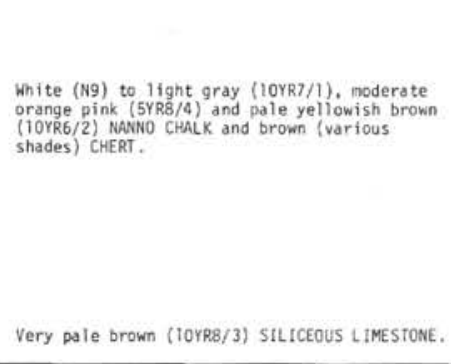 \\
\hline
\end{tabular}

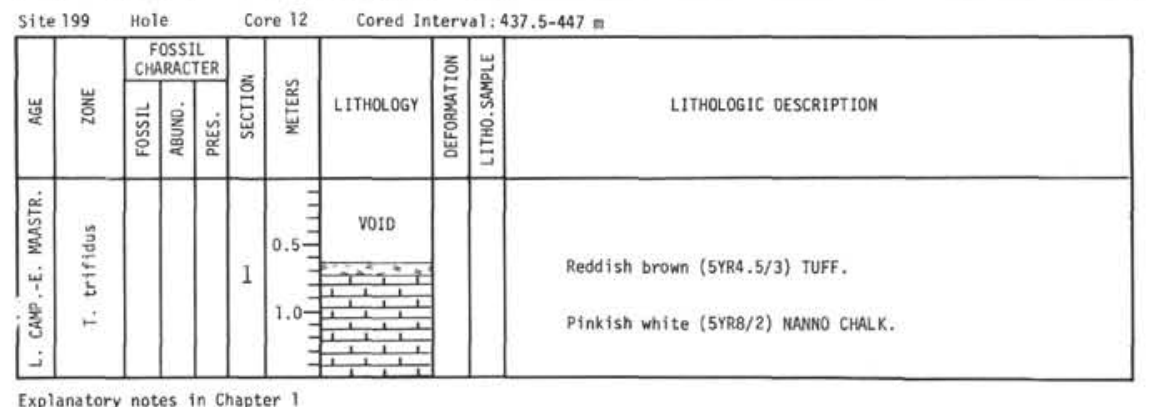

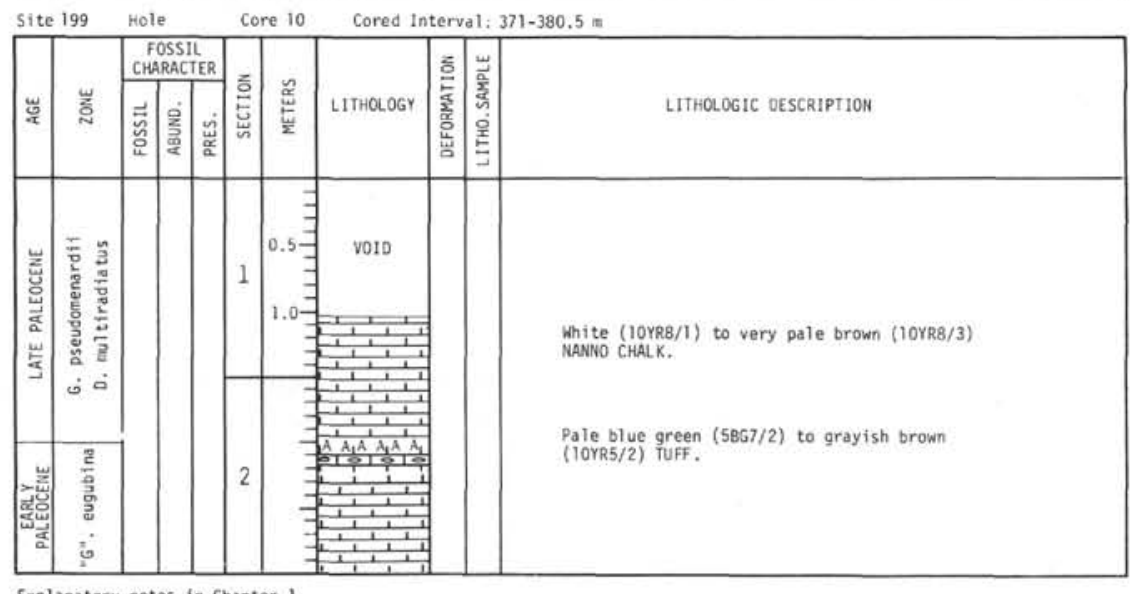

Explanatory notes in Chapter 1 


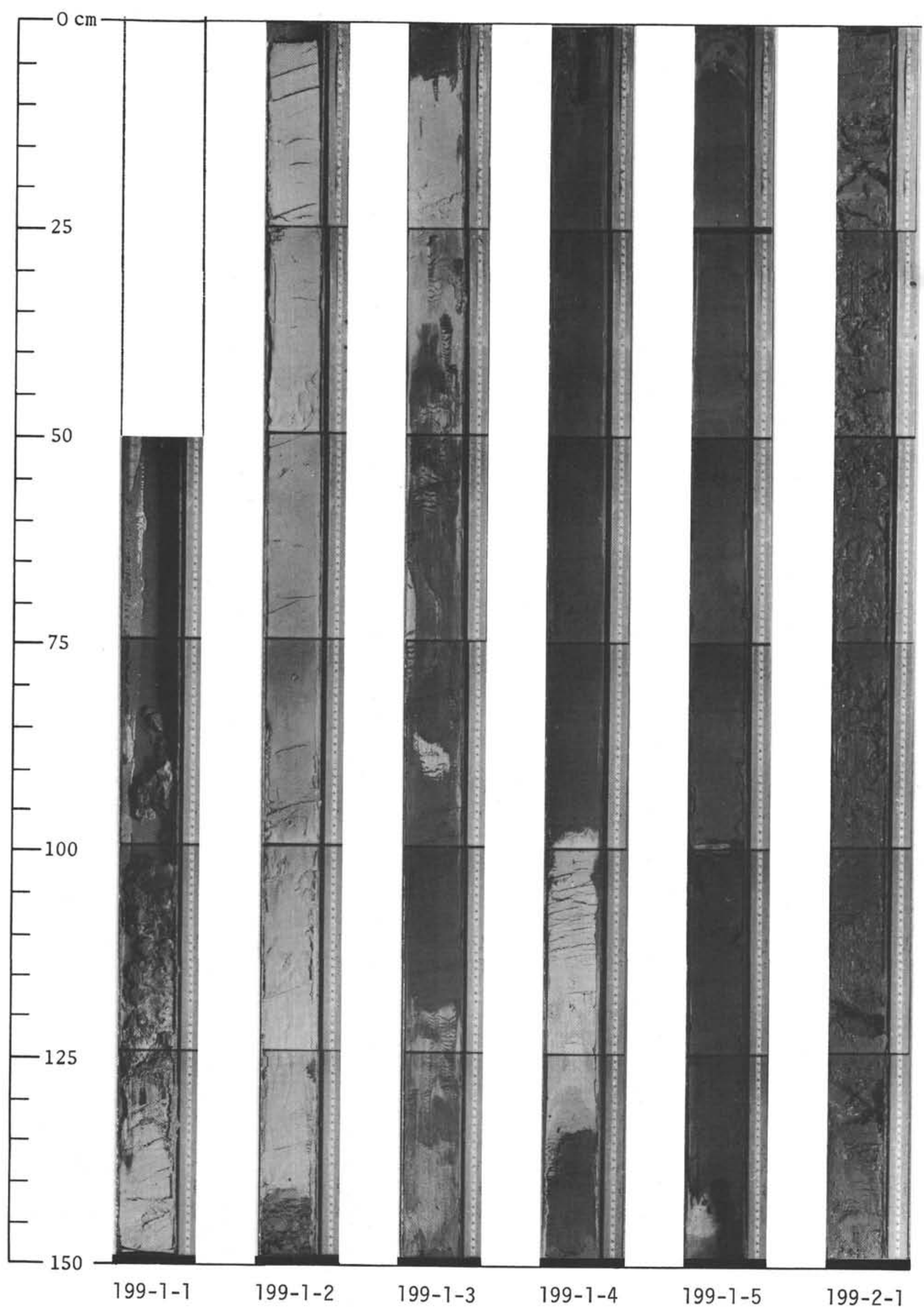




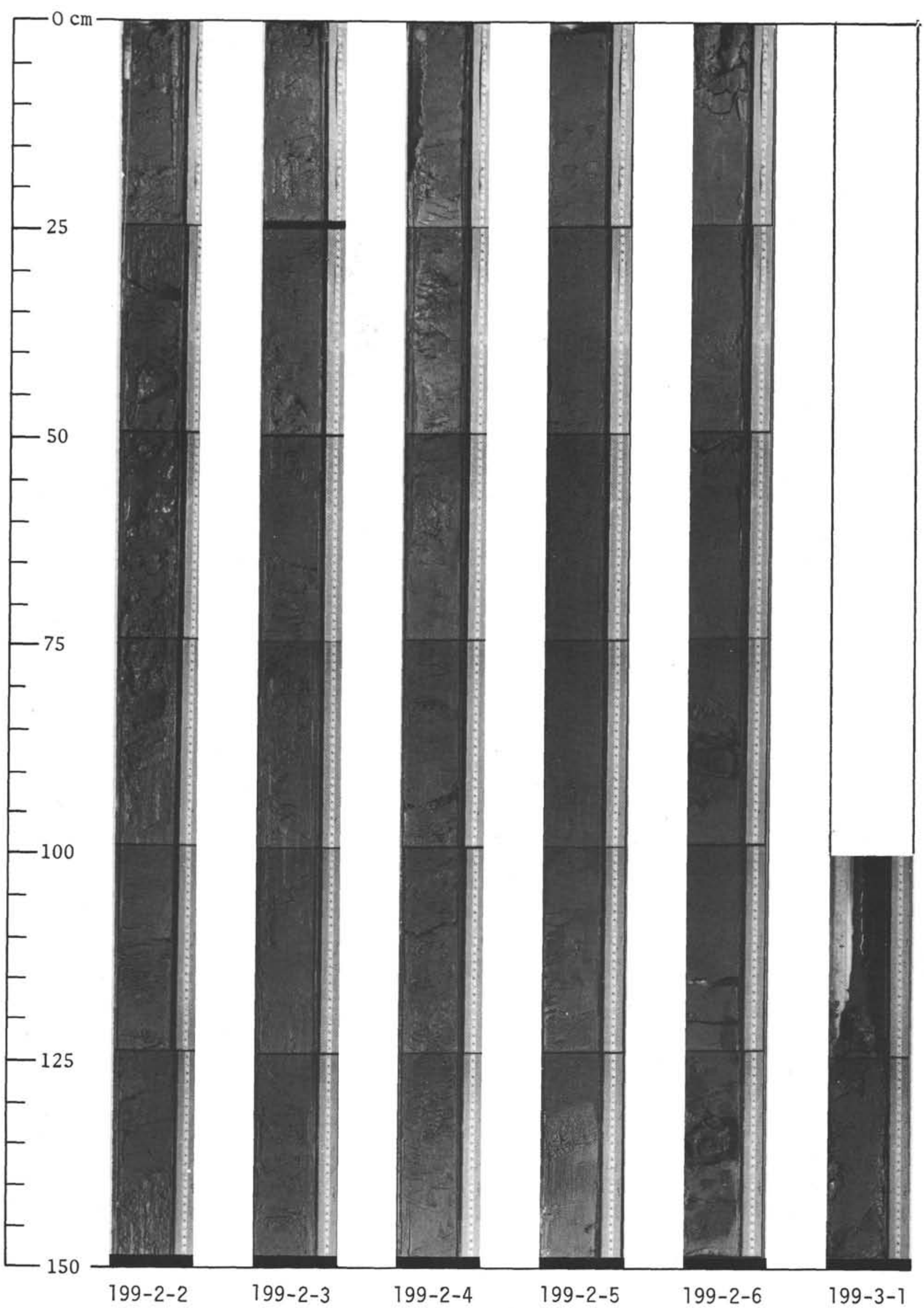




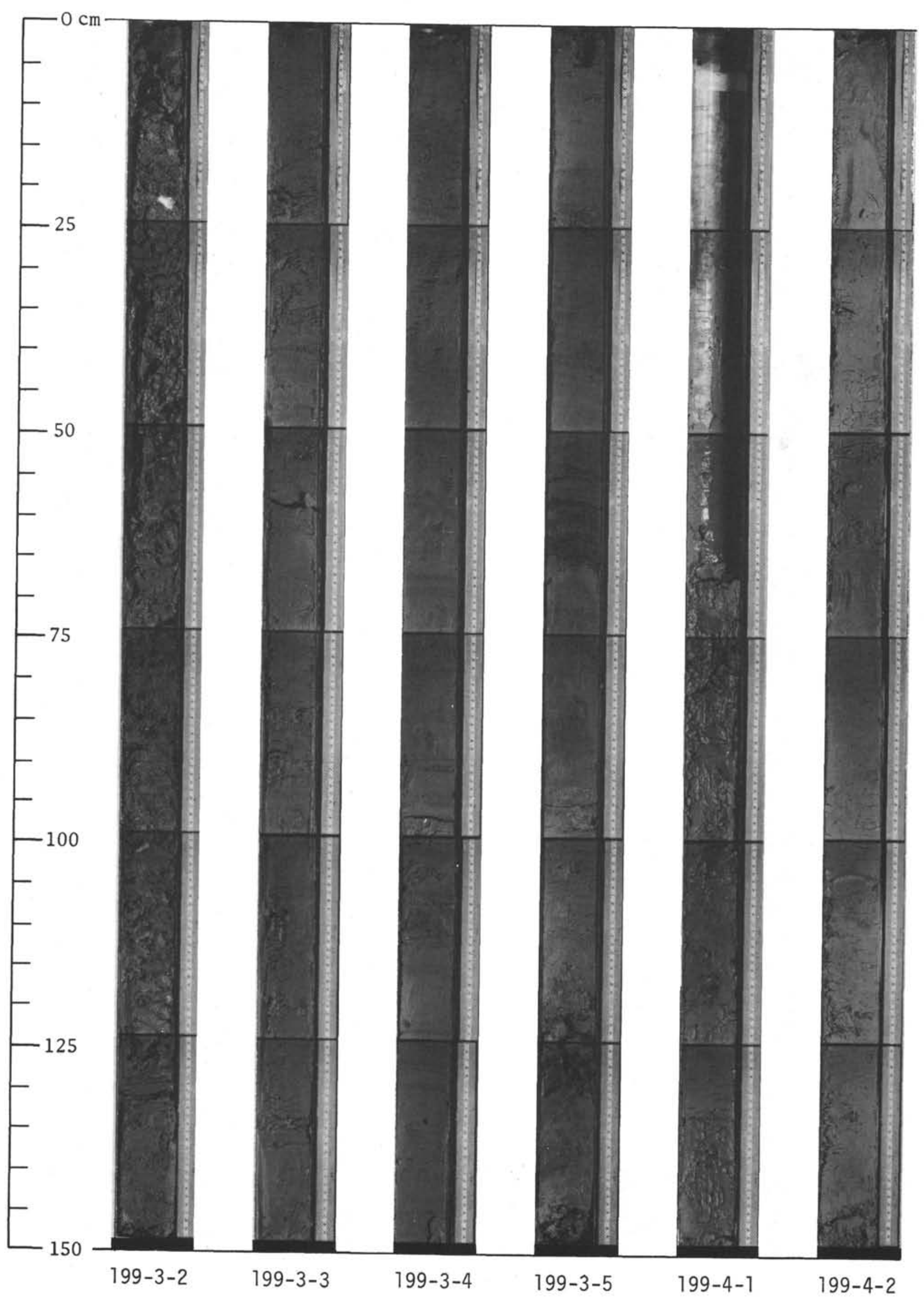




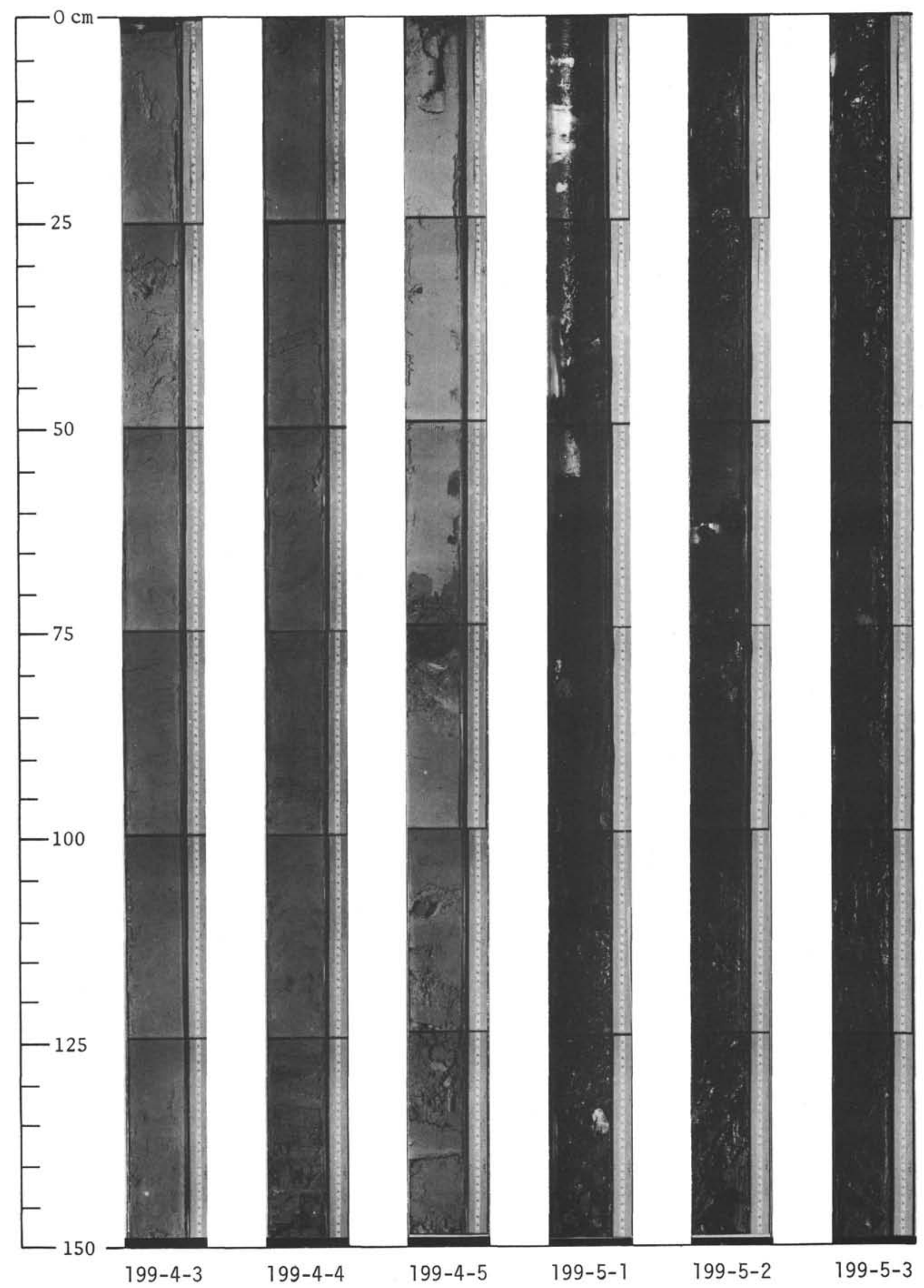




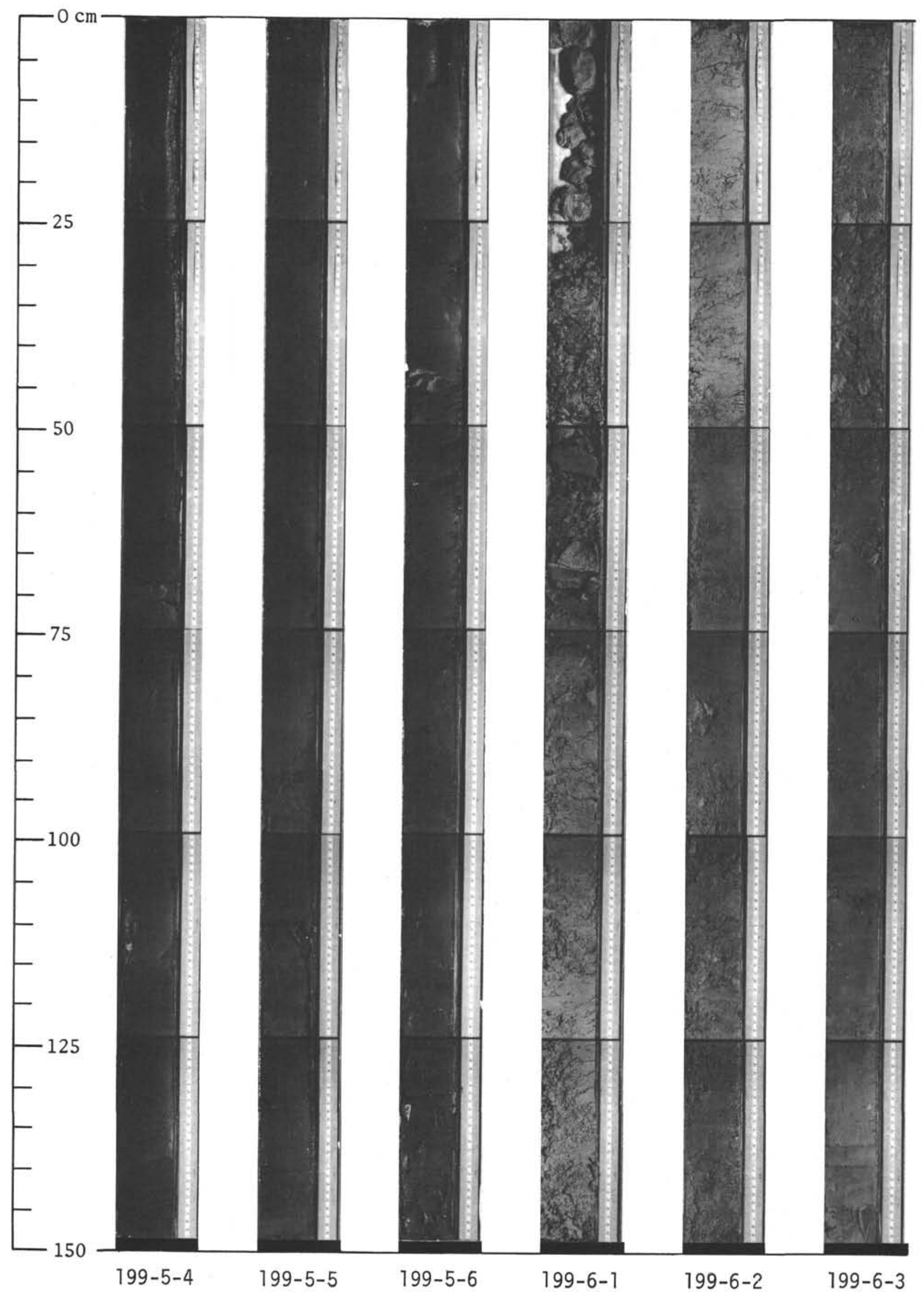




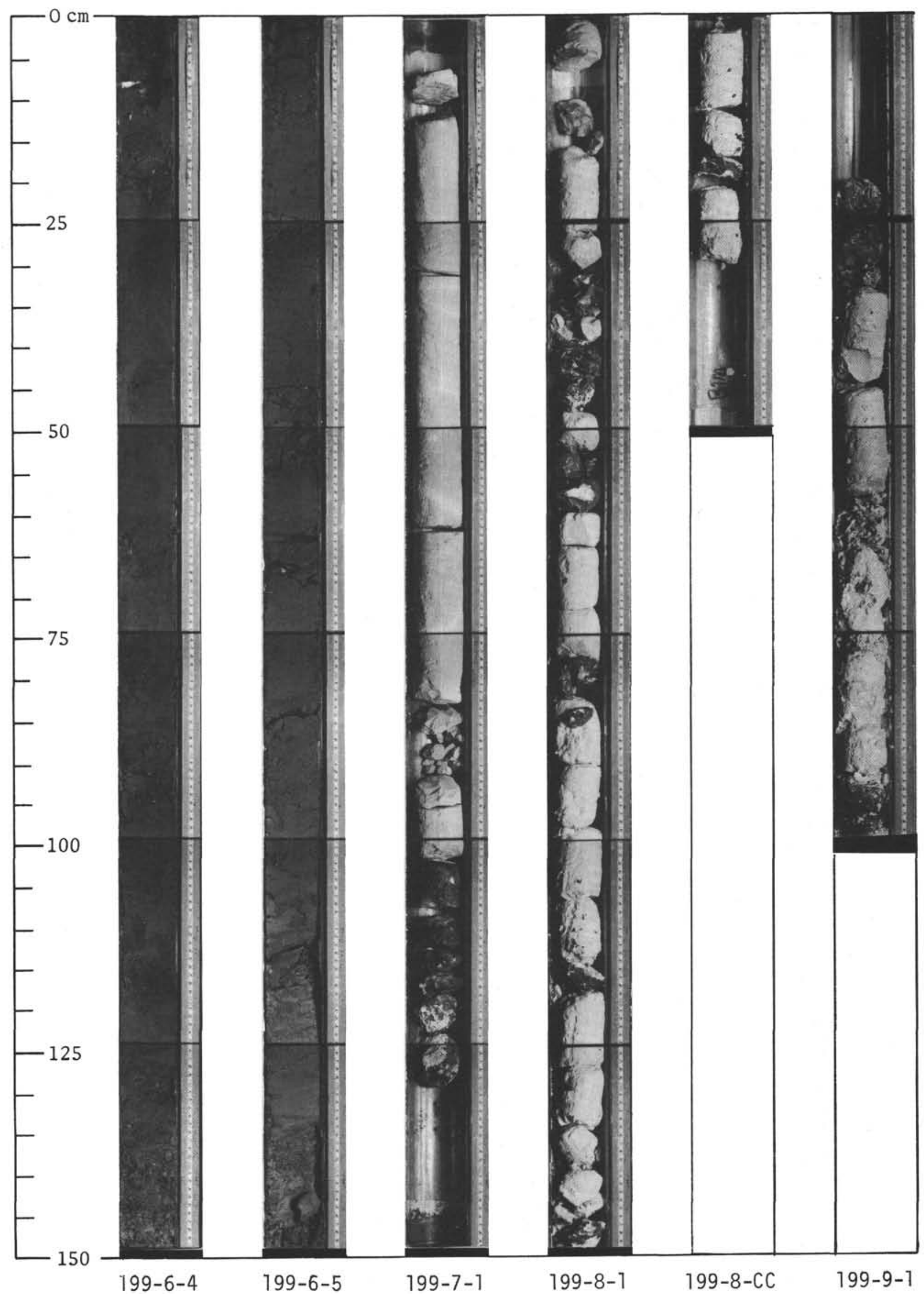




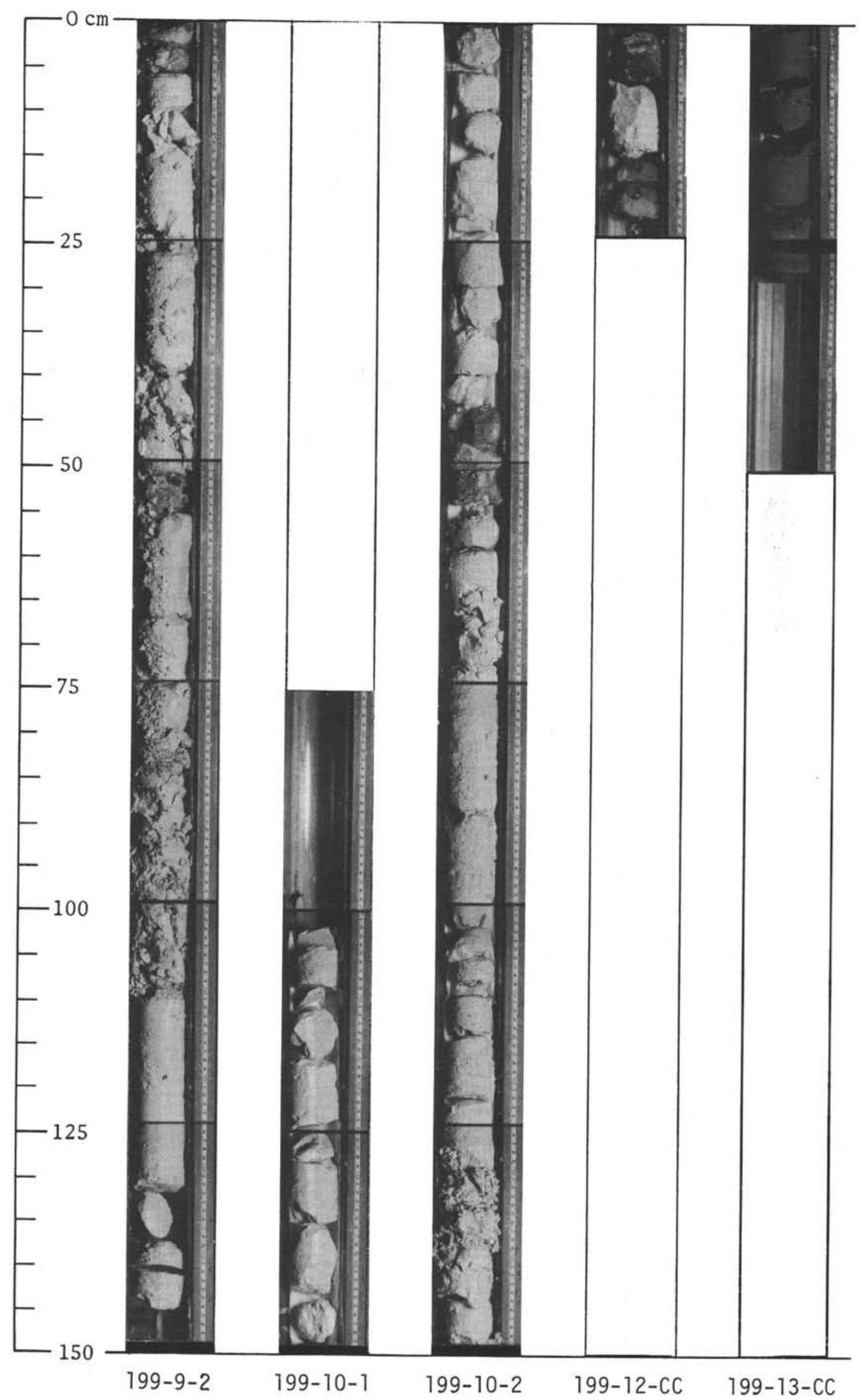

